\title{
Sex-Bias in Irritable Bowel Syndrome: Linking Steroids to the Gut-Brain Axis
}

\author{
Sik Yu So ${ }^{1,2}$ and Tor C. Savidge ${ }^{1,2 *}$ \\ ${ }^{1}$ Department of Pathology and Immunology, Baylor College of Medicine, Houston, TX, United States, ${ }^{2}$ Texas Children's \\ Microbiome Center, Department of Pathology, Texas Children's Hospital, Houston, TX, United States
}

OPEN ACCESS

Edited by:

Cristina Giaroni,

University of Insubria, Italy

Reviewed by:

Giada De Palma,

McMaster University, Canada

Valentina Caputi,

University College Cork, Ireland

*Correspondence:

Tor C. Savidge

Tor.Savidge@bcm.edu

Specialty section:

This article was submitted to

Gut Endocrinology,

a section of the journal

Frontiers in Endocrinology

Received: 22 March 2021 Accepted: 03 May 2021

Published: 19 May 2021

Citation:

So SY and Savidge TC (2021) SexBias in Irritable Bowel Syndrome: Linking Steroids to the Gut-Brain Axis.

Front. Endocrinol. 12:684096. doi: 10.3389/fendo.2021.684096
Irritable bowel syndrome (IBS) is a functional gastrointestinal disorder that is more common in females. Despite its high global incidence, the disease mechanism is still unclear and therapeutic options remain limited. The sexual dimorphism in IBS incidence suggests that sex steroids play a role in disease onset and symptoms severity. This review considers sex steroids and their involvement in IBS symptoms and the underlying disease mechanisms. Estrogens and androgens play important regulatory roles in IBS symptomology, including visceral sensitivity, gut motility and psychological conditions, possibly through modulating the gut-brain axis. Steroids are regulators of hypothalamicpituitary-adrenal activity and autonomic nervous system function. They also modulate gut microbiota and enteric nervous systems, impacting serotonin and mast cell signaling. Sex steroids also facilitate bidirectional cross-talk between the microbiota and host following bacterial transformation and recycling of steroids by the intestine. The sex-specific interplay between sex steroids and the host provides neuroendocrinology insight into the pathophysiology, epigenetics and treatment of IBS patients.

Keywords: sex steroids, irritable bowel syndrome, gut-brain axis, gut microbiota, androgens, estrogens

\section{INTRODUCTION}

Irritable bowel syndrome (IBS) is a common functional gastrointestinal (FGID) disorder that is characterized by abdominal pain and disturbances in bowel habit. It is classified according to predominant stool patterning into several subtypes, which include IBS with constipation (IBS-C); IBS with diarrhea (IBS-D); IBS with mixed stooling patterns (IBS-M); and unsubtyped IBS (IBS-U). Irrespectively of bowel habit, IBS is diagnosed based on symptoms experienced, notably using Rome definitions that were recently updated to Rome IV criteria (1). The global prevalence of IBS is estimated at $9.2 \%$ versus $3.8 \%$ based on diagnosis by Rome III and Rome IV criteria, respectively (2). Not only do IBS patients suffer from abdominal discomfort, but their quality of life is also impacted by extra-intestinal symptoms including anxiety, depression, headache and fatigue $(3,4)$. Major limitations in the field include uncertainty regarding IBS disease etiology and limited therapeutic options that show efficacy in subpopulations of patients only. Notably, females are more frequently diagnosed with IBS and clinical symptoms tend to be more severe $(2,5)$. The sex-bias in IBS was recently reviewed (6-8), suggesting that sexual dimorphism and sex steroids could be involved in the pathophysiology, a view supported by symptoms being linked to estrous cycle (9) and the 
absence of X-linked genetic susceptibility (10). Building on this previous body of work, here we provide a deeper dive into sex steroids and their involvement in IBS symptoms, focusing on their molecular mechanism of action and impact on the microbiome-gut-brain axis.

\section{CURRENT EVIDENCE ON SEX AND IBS INCIDENCE}

IBS is more common in females $(2,11)$. This trend was also found in children (12), although some inconsistent results have been reported (13). While IBS prevalence is constant with age in males (14), disease prevalence in females is age and hormonal status dependent. Some inconsistencies are reported, for example a few notable studies report a reduction in IBS incidence after menopause, whereas others show exacerbated FGID symptoms $(15,16)$. Sex is also a determinant of IBS subtype, with constipation being predominant in females, whereas diarrhea is more frequently diagnosed in males $(17,11)$. Females are also more likely to suffer from more severe clinical symptoms (5), although other studies did not report a sex-bias in disease severity. A number of confounding factors such as cultural differences could contribute to this discrepancy. For example, in India males are diagnosed with IBS more frequently than females, but this may be linked to males being more likely to consult a physician (18). Conversely, in Europe and North America, physician IBS consultations are reported as femalebiased (11). Nevertheless, the literature generally supports sexual dimorphism in IBS and suggests that sex-related physiological differences, such as sex steroids could be related to disease onset and symptoms severity (Figure 1).

\section{SEX STEROIDS}

Sex steroids play an important role in reproductive system homeostasis, as well as in other physiological processes. There are three main types of sex steroids: namely estrogens, androgens and progesterone. Among these, this review focuses mainly on estrogens and androgens. Estrogens are mainly produced in the ovaries in premenopausal women, whereas the testis or other peripheral organs are involved in hormone production in men (Figure 2). The major forms of estrogens are estradiol, estrone and estriol. The estrogen forms exhibit varied potencies and play different roles during development. For instance, estradiol is the most abundant and potent estrogen during female reproductive years, while estrone predominates after menopause (19). Estrogens bind to and activate classical estrogen receptors (ER), including receptor $\alpha(\mathrm{ER} \alpha)$ and $\beta(\mathrm{ER} \beta)$ isoforms which belong to the family of nuclear hormone receptors (NHRs) that translocate to the nucleus where they bind to DNA and mediate the genomic effects of estrogens (20). Estrogens also bind to membrane-bound receptors, such as G-protein-coupled estrogen receptor (GPER) to exert non-genomic effects. Upon binding and activation, GPER triggers downstream pathways and regulates a wide range of activities, including cellular differentiation and proliferation.

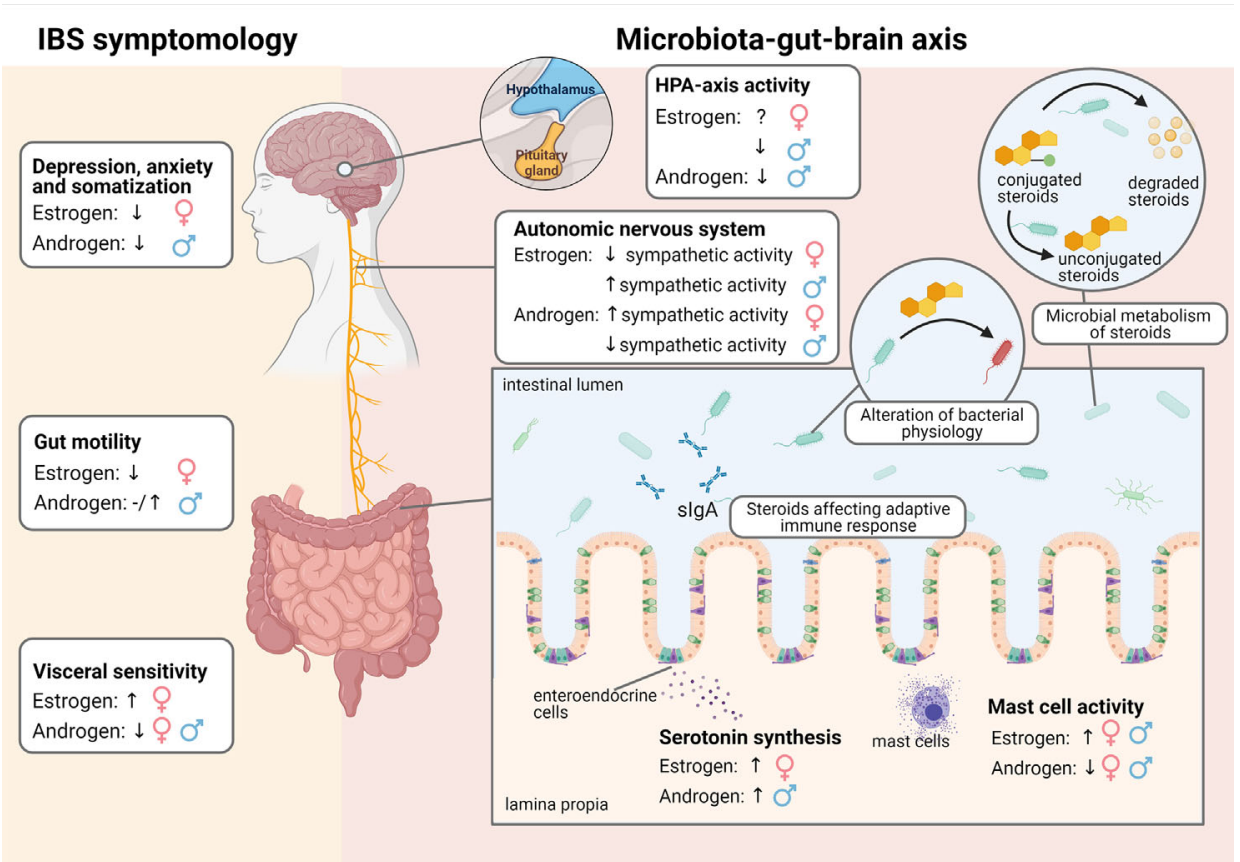

FIGURE 1 | Effect of estrogens and androgens on IBS symptomology and the microbiota-gut-brain axis in males and females. 


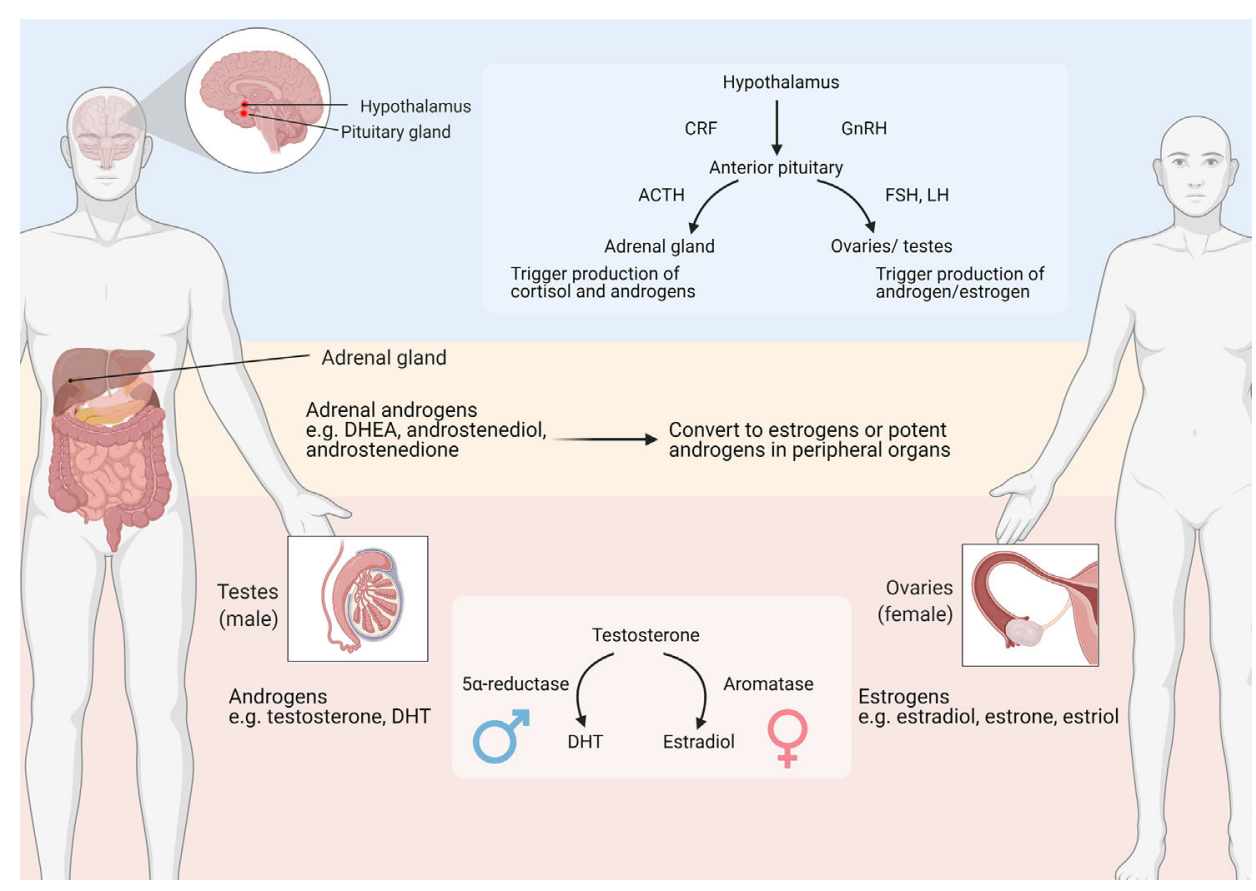

FIGURE 2 | Major organs involved in sex steroids production. ACTH: adrenocorticotropic hormone; CRF: corticotropin-releasing factor; DHEA, dehydroepiandrosterone; DHT, Dihydrotestosterone; FSH, Follicle-stimulating hormone; GnRH, Gonadotropin-releasing hormone; LH, Luteinizing hormone. Adapted from "Primary and Secondary Endocrine Organs" by BioRender.com (2021). Retrieved from https://app.biorender.com/biorender-templates.

Androgenic steroids mainly include testosterone and dihydrotestosterone (DHT). Androgens are mostly produced by the testis in males, and are derived from the ovaries or adrenal glands in females (Figure 2). Androgens bind to and activate the androgenic receptor (AR), another member of NHRs. Similar to estrogens, androgens also activate membrane-associated receptors, including $G$ protein-coupled receptor class $\mathrm{C}$ group 6 member A (GPRC6A) and the zinc transporter ZIP9 (21). Androgens can be converted into estrogen, through an enzymatic process catalyzed by aromatase that occurs preferentially in females (Figure 2).

The adrenal glands produce various adrenal C19 steroids, also known as the adrenal androgens, including dehydroepiandrosterone (DHEA), androstenediol, androstenedione and $11 \beta$ hydroxyandrostenedione (22). These steroids are usually weaker ligands of androgen and estrogen receptors, but they represent significant circulating precursors for peripheral conversion to potent androgen and estrogen forms. After release from the adrenal cortex, adrenal steroids are converted to testosterone or DHT through enzymatic reactions that contribute substantially to circulating testosterone levels in pre-pubertal children and women. Furthermore, the 11-oxygenated androgen 11ß-hydroxyandrostenedione is released in significant quantities by the adrenal glands, and contributes to the synthesis of 11-keto-testosterone and 11-keto-dihydrotestosterone which have similar androgen receptor activation potential compared to testosterone and DHT (23-25). These studies demonstrate that adrenal androgens are also important when studying the potential role of sex steroids in IBS patients.
Sex steroids play a critical role in many processes including gender development, skeletal growth, brain function, etc. They are also associated with various diseases, including obesity, Alzheimer's disease, autism in males and females. For instance, testosterone deficiency is associated with obesity and insulin resistance in males (26); while excessive testosterone is associated with these traits in females (27). The decline in sex hormone levels with advancing age also causes undesirable agingassociated outcomes, for example reduced estrogen around menopause leads to menopausal symptoms and osteoporosis in females. Despite the low androgenic potency, adrenal C19 steroids are considered neuroactive due to their ability to modulate neuroreceptors such as GABA A receptors (28). These steroids play an important regulatory role in various functions, for example cognition, anxiety and depression. Detailed physiological studies that investigate how sex steroids are associated with IBS disease onset and symptoms are therefore warranted.

\section{ASSOCIATION OF SEX STEROIDS WITH IBS SYMPTOMS AND TREATMENT}

The female predominance of IBS indicates that ovarian hormones, particularly estrogens could act as disease modulating signals. For example, a recent study reported significantly higher serum estradiol in females with IBS than 
healthy controls (29). While most IBS-related studies have focused on estrogen and ovarian hormones, several studies have also investigated the role of androgens in disease incidence. Males with IBS exhibited less male characteristics when assessed using a male-trait score (30), demonstrating a potential role for androgens. However, a study found higher testosterone in male IBS patients compared to healthy controls (31). In females, patients with polycystic ovary syndrome have higher androgen levels and IBS risk than other females (32). A more systematic evaluation of sex steroid levels in IBS, paying careful attention to age and methodological variables is therefore needed.

\section{Visceral Hypersensitivity}

One key clinical manifestation of IBS is visceral hypersensitivity, which refers to the heightened sensation to physiological stimuli in visceral organs. Females generally demonstrate higher sensitivity to pain (33-35). Yet, a recent report questioned this generalization after finding no sex differences in visceral sensitivity in young healthy participants (36). Animal studies show that sex steroids, in particular estrogen, are important regulators of visceral hypersensitivity and contribute mechanistically in a number of ways. Estrogens are generally reported to increase visceral sensitivity (37-39). However, sex and concentration of estrogens may affect their mechanisms of action. For example, one study reported that administration of high levels of estradiol is analgesic only in female but not male rats (40). Expression and activation of estrogen receptors also appears to be important, with $\mathrm{ER} \alpha$ and GPER receptor expression being upregulated and correlated positively with gut pain in patients with IBS-D (41). Estrogen receptors are distributed along the entire visceral pain sensation pathway in rodents (42-44). It is therefore reasonable to assume that estrogens modulate visceral sensitivity at both peripheral and central nervous system levels. In the periphery, estrogens modulate nociceptive responses through altering ion channel opening, G-protein coupled signaling and nociceptive receptor expression (45). Among the ion channels, the transient receptor potential vanilloid-1 (TRPV1) channel is involved in thermal and pain sensation and is well recognized to play an important role in visceral hypersensitivity. TRPV1-expressing sensory fibers are increased in colonic tissue from IBS patients and are positively correlated with abdominal pain score (46), reflecting the potential involvement of TRPV1 in IBS. After activation, the entry of calcium ions transduce the release of neuropeptides or excitatory compounds which activate pain transmission pathways and eventually lead to visceral pain and IBS symptoms (47). Estrogens sensitize TRPV1 and upregulate TRPV1 expression in sensory neurons in rodents and in vitro studies (48-50). This response could contribute to the sexual dimorphism of pain perception. Estrogens can modulate TRPV1 expression via genomic or non-genomic regulatory pathways. For genomic action, estrogens bind to ER, which translocates into the nucleus, binds DNA estrogen response elements (ERE) in the promoter region of the TRPV1 gene and upregulates transcription of TRPV1 (51). Other mechanisms can also promote estrogen modulation of hypersensitivity, including regulation of opioid receptors (52).

In contrast to estrogens, androgens are usually reported as antinociceptive. In rats, estradiol increases stress-induced visceral hypersensitivity in males, while testosterone reduces it in females (38). In a study of male rats, testosterone negatively correlated with rectal sensory threshold to balloon distension (53), suggesting a protective role of androgens. However, other studies reported that testosterone does not influence visceral pain in either male or female animal models (40). Androgens also modulate the TRP family, including TRPV1, but transient receptor potential melastatin 8 (TRPM8) represents the main target of androgens $(54,55)$. TRPM8 is a receptor involved in cold perception and treatment with DHT elevates TRPM8 expression in vitro (56). Compared with TRPV1, the involvement of TRPM8 in IBS and pain perception is less clear and needs further study. A report investigating TRPM8 polymorphism found an association with increased IBS risk (57). While TRPM8 is suggested to possess both pro- and antinociceptive roles in the intestine (58), ligands of TRPM8 such as peppermint are believed to possess analgesic effects in IBS patients $(59,60)$. Mechanistically, these anti-nociceptive properties could be mediated through activation of TRPM8 on peripheral sensory neurons, which subsequently desensitizes TRPV1 activation (58). Altogether, androgens possibly could reduce visceral pain through enhancing TRPM8 expression and/ or activity.

\section{Gastrointestinal Dysmotility}

Another key clinical manifestation of IBS is altered gastrointestinal motility, which also defines IBS subtypes. In general, intestinal transit is slower in women than in men (61) (62-64), and could contribute to the predominance of IBS-C in females versus IBS-D in males. Estrogens delay intestinal motility, possibly through modulation of the nitric oxide (NO)/cyclic guanosine monophosphate (cGMP) pathway via ER and GPER activity. Sex-related differences in gut motility could also relate to higher ER $\alpha$ and ER $\beta$ expression in females (65). Elevated ER expression in females is linked to increased responses to estrogens with stimulation of nitric oxide (NO) and cGMP secondary messengers, resulting in activation of smooth muscle relaxation. Similar to ER, GPER-coupling inhibits intestinal motility by stimulating NO release (66). GPER agonist G1 and estradiol prolong colonic transit times in both male and female mice and inhibit colonic muscle contraction in vitro (67). Also, administration of GPER antagonist G15 reduces colonic transit time and inhibits the effect of estradiol in female mice (66). Even though GPER mRNA levels are reported to be higher in IBS-D compared with IBS-C patients or healthy individuals $(68,41)$, the consensus opinion favors involvement of GPER in alteration of bowel movement in IBS. In addition to estrogen receptors, TRPV1 may also play a role in motility disorders (69), although the results have been conflicting. A study reported that activation of TRPV1 causes neuronal release of tachykinins which mediate an increase in gut motility (70); whereas another study showed inhibition of jejunal motility by 
TRPV1 through the NO signaling pathway (71). The different doses of agonist administered could represent a confounding factor (72). Little evidence is available to understand the regulatory role of androgens on gastrointestinal motility. The impact of testosterone ranges from showing no influence on intestinal motility in male rats (73), to more recent studies reporting that androgens induce intestinal smooth muscle contraction through a non-genomic calcium sensitization pathway in intestinal tissues from male rodents $(74,75)$. Further investigations are required to confirm whether and how androgens influence gut motility.

\section{Psychological Symptoms}

Apart from gastrointestinal discomfort, IBS patients often suffer from psychological symptoms, including depression, anxiety and somatization (Figure 1). Women are more commonly affected by these symptoms than men, in both IBS patients (76-78) and healthy individuals (79-81). Low levels of hormones are closely associated with these psychological symptoms and fluctuations in ovarian hormones contribute to mood-related symptoms in females. For instance, depression and anxiety are common symptoms of premenstrual syndrome (PMS), which occurs when estrogen and progesterone levels decrease during the menstrual cycle (82). Estrogen receptors however exert divergent effects, which could contribute to the inconsistent effects reported for estrogen treatment on anxiety (83). Meanwhile, androgen deficiency and AR dysfunction contribute to anxiety and depression in male rodents, whereas testosterone therapy alleviates the symptoms in men $(84,85)$. Moreover, the adrenal androgen DHEA exhibits antidepressant properties and is reduced during depression $(86,87)$.

\section{Relationship Between Estrous Cycle and Gastrointestinal Symptomatology in IBS}

The female predominance of IBS highlights the potential role of ovarian steroids in the pathophysiology. Fluctuations of gastrointestinal symptoms during the estrous cycle demonstrate the importance of ovarian steroids. The estrous cycle is mainly divided into menstrual phase, follicular phase, ovulation and luteal phase. Estrogens increase during the follicular phase, and drop rapidly at ovulation. Levels of estrogen and progesterone then increase gradually and dominate during the early luteal phase. Women have prolonged gastrointestinal transit times at this stage compared to the follicular phase $(64,88)$. During the perimenstrual phase when ovarian hormones are generally at their lowest levels, women experience enhanced visceral sensitivity and gut pain (89). Furthermore, IBS patients often experience enhanced symptoms during menses (90). Houghton et al. 2002 reported that rectal sensitivity was increased during menses in IBS patients but not in healthy volunteers (91). Other examples demonstrating the effect of sex steroids on gastrointestinal function include hormone therapy and pregnancy which are suggested to influence gut motility and visceral sensitivity (92-94). How sex steroids impact motility and psychological symptoms in IBS is likely closely related to gut-brain-axis signaling and include mechanistic components such as serotonin function and the HPA axis which are considered in the next section.

\section{Therapeutic Options}

Sex-dependent efficacy of currently available IBS treatments has been reported in various studies and was reviewed recently (95). Males and females are found to respond differently to some treatments. For example, alosetron which targets the serotonergic pathway is more effective in females, possibly due to sex differences in drug metabolism and receptor-signaling (discussed in later section) $(96,97)$. However, there are limited studies that directly evaluate how sex steroids affect the action of IBS treatments. When considering their close association with IBS symptomology, it is possible that sex steroids modulate treatment efficacy. For example, peppermint oil efficacy against IBS contains menthol, a TRPM8 activator, as the bioactive ingredient (98). As androgens also target TRPM8, it could influence the efficacy of peppermint oil through ion channel competition. It is therefore important to evaluate how sex steroids may influence and predict treatment outcomes.

\section{SEX STEROIDS AND THE GUT-BRAIN AXIS IN IBS}

One of the major disease mechanisms proposed in IBS is gutbrain axis dysregulation. Neuroimaging studies demonstrate that patients with IBS have different brain morphology when compared with healthy individuals $(99,100)$, suggesting significant contributions of altered brain circuits in IBS development. Researchers have focused on several components of the gut-brain axis in IBS. Stress is one of the risk factors associated with onset and exacerbation of IBS. For instance, a recent study reported that stress during the COVID-19 pandemic exacerbated clinical symptoms in IBS patients (101). Stress response mechanisms could therefore play an important regulatory role in IBS pathophysiology.

\section{Hypothalamic-Pituitary-Adrenal (HPA) Axis}

IBS patients are more likely to have been exposed to stress as early adverse life events (102-105), which is often related to dysregulation of the HPA axis (Figure 1). Among IBS patients, those who experienced childhood trauma are more likely to suffer from somatization and psychological distress (106). The HPA axis is an important component of the neuroendocrine system and plays a pivotal role in mediating the stress response. In response to stress, corticotropin-releasing factor (CRF) is released from the hypothalamus. This results in the release of adrenocorticotropic hormone (ACTH) from the pituitary gland, which causes the adrenal cortex to release glucocorticoid hormones, such as cortisol, which in turn downregulates the pathway as a negative feedback loop (107). The HPA axis is related to various stress responses, including visceral sensitivity and depression, and is dysregulated in IBS (108), although the exact association between IBS symptoms and the HPA response is not consistently reported. In some studies the HPA axis response is enhanced in IBS patients compared with controls (109-111), while another study reported the opposite finding 
(112). Yet another study reported that the HPA response in IBS patients was enhanced in males but blunted in females (113), demonstrating the importance of considering sex-bias when considering the stress response in IBS.

HPA axis activation related to sex-bias is also controversial $(113,114)$. Different hormonal status such as estrous cycle, menopause and pregnancy are known to influence the HPA axis. Despite numerous studies reporting alteration of HPA axis signaling by sex steroids, their exact effect is still inconclusive. In animals, ovariectomy which removes endogenous estrogens in females reduces the HPA response to stimulation or stress, while supplementation of estradiol increases and restores the response (115-118). However, other studies reported an inhibitory effect $(119,120)$. This discrepancy could be due to dose and duration of treatment, as well as model differences and health status of the animals (121). In humans, while a study reported that estradiol enhanced the HPA response in men (122), studies in postmenopausal women reported the opposite response (123). In addition to the confounding factors referenced above, the type of receptors involved also influence the effect of estrogens. Activation of $\mathrm{ER} \alpha$ exerts stimulatory effects on the basal state and during restraint stress, whereas activation of ER $\beta$ inhibits the HPA-axis only when this is activated $(117,124)$.

In contrast to estrogens, androgens generally inhibit HPA axis activity. Castration in male animals enhances HPA axis activity, while androgen treatment inhibits the activity $(117,118,125$, 126). The same effect of androgen supplementation are found in humans (127). In male mice with dysfunctional AR signaling, the HPA axis response to stress is elevated $(128,129)$, demonstrating that $\mathrm{AR}$ is involved in HPA axis suppression. DHT, a strong AR ligand, is often used to examine the effect of androgens and is shown to inhibit the HPA axis. As DHT cannot be converted into estradiol, its effect is not likely due to aromatization. Conversely, DHT can be metabolized into Androstan-3,17-diol (3ß-diol) which binds to ER $\beta$ and could exert an inhibitory effect on the HPA axis. Thus, the conversion of DHT into $3 \beta$-diol and ER $\beta$ activation could mediate some of the effects of DHT (117).

\section{Autonomic Nervous System}

In addition to the HPA axis, the autonomic nervous system is also a major component of the stress response. It consists of the sympathetic nervous system and parasympathetic nervous systems. While the sympathetic nervous system prepares the body for the 'fight or flight' response, the parasympathetic system restores the body to a relaxed state. The autonomic nervous system regulates body functions such as arterial pressure and heart rate, as well as numerous gastrointestinal functions including blood flow, peptide hormone release, visceral sensitivity and gastrointestinal motility. The autonomic system is reported to be disturbed in IBS. In general, sympathetic activity is upregulated while parasympathetic signals are downregulated in IBS (130), but the alterations could be dependent on IBS type and sex. Generally, males have higher sympathetic activity, while females have higher parasympathetic activity. Some studies focusing on females reported elevated sympathetic signaling with inhibition of the parasympathetic activity in IBS (131, 132). In another female IBS study, autonomic function was similar in IBS patients and healthy controls; while parasympathetic activity was lower in IBS-C than IBS-D patients (133). A separate study found that autonomic imbalance in IBS preferentially occurs in males (130).

Not surprisingly, the sexual dimorphic findings in autonomic neuronal function relate to sex hormones modulating this system. For instance, sympathetic activity is often increased in the luteal phase of the menstrual cycle or during menopause when estrogen levels are reduced (134). A study reported that surgical-induced menopause reduced parasympathetic nervous system activity and shifted this towards sympathetic hyperactivity (135). Although some studies found no effect $(136,137)$, others reported that estrogens in hormone replacement therapy facilitate parasympathetic activity and suppress sympathetic signaling in postmenopausal women (138-140). Estrogen may reduce sympathetic fiber density directly through affecting $\mathrm{ER} \alpha$ expressed in sympathetic neurons, or indirectly through affecting target tissue or specific molecules (141). However, another study reported that estrogen is positively correlated to sympathetic activity in men (142). Nevertheless, estrogens are generally reported to inhibit sympathetic activity while sex could possibly influence the effect.

In contrast to estrogens, androgens are associated with sympathetic hyperactivity in females. In polycystic ovary syndrome patients, who often suffer from hyperandrogenism, sympathetic activity was enhanced whereas parasympathetic signaling was suppressed (143). Furthermore, excess neonatal androgen in female mice increases sympathetic tone in cardiometabolic tissues (144). However, several studies reported that androgens are positively correlated with parasympathetic activity in males $(142,145)$. Also, a study found that males with low testosterone levels were unable to maintain cardiosympathetic and cardiovagal responses (146). These inconsistent findings suggest that autonomic control mediated by sex steroids could be sex-dependent, as well as modulated by health and hormonal status of the individual.

\section{Enteric Nervous System}

The enteric nervous system is often referred to as the "little brain" or 'brain-in-the-gut' and is the largest division of the peripheral nervous system. It is also considered as the third division of the autonomic nervous system. A distinguishing feature is it can act independently of the brain, but usually communicates with the CNS for regulation of enteric function and information transmission to the brain. The enteric nervous system is generally organized into submucosal and myenteric plexi that connect to the gut lumen via enteroendocrine cells in the epithelial layer and to the brain by vagal, spinal and sacral afferent nerves (147). The enteric nervous system regulates secretion and absorptive capacity in the intestine, as well as motility. In a rodent IBS model, animals exposed to stress exhibited more secreto-motor neurons in the submucosal plexus and less inhibitory musculo-motor neurons in myenteric plexus (148). There are also sex-dependent differences in the enteric nervous system, for example distinct structural and functional characteristics of enteric neurons in pigs $(149,150)$. Numerous components related to enteric 
nervous system function are influenced by IBS and sex steroids, although these tend to be more subtle.

Serotonin (5-HT) is a neurotransmitter closely associated with central and enteric nervous system function. It represents a central regulator of diverse physiological activities, including sleep, mood and cognition. It also plays an important role in visceral sensitivity and gut motility (151). Although serotonin is produced by central and peripheral nervous systems, the primary source is from the gut enteroendocrine cells that also express chemosensory receptors and transmit sensory signals from the gut lumen to the nervous system. Upon local mucosal stimulation, enteroendocrine cells secrete 5-HT which activates $5-\mathrm{HT}_{3}$ and $5-\mathrm{HT}_{4}$ receptors on enteric neurons to facilitate motor and sensory responses (152). Serotonin levels are affected by sex and hormonal status associated with estrous cycle. Compared with females, males have higher 5-HT synthesis rates in the brain after acute tryptophan depletion (153). Female IBS patients show greater 5-HT synthesis in the brain compared with healthy females, while this difference was not evident in IBS males (154). The sex difference in 5-HT signaling pathways in IBS can also be seen in response to drugs. For instance, $5-\mathrm{HT}_{3}$ receptor antagonists, including alosetron is more effective in females than males (96). Estrogens promote serotonin synthesis (155) and animals with an ovariectomy have reduced serotonergic neuronal numbers and expression of 5-HT related genes (156). It is believed that the drop in estradiol levels during menopause or after giving birth reduces serotonin activity and causes mood disorders (157). Estrogens also modulate the expression of the serotonin reuptake transporter (SERT) (158), which retrieves released serotonin into neurons and controls the amount of bioavailable circulating neurotransmitter. This effect was reported to be dependent on the drug exposure length (159). Furthermore, estrogens affect 5-HT receptor expression. For instance, estradiol upregulates the density and ligand binding to the $5 \mathrm{HT} 22_{\mathrm{A}}$ receptor in brain in postmenopausal women (160, 161). The $5 \mathrm{HT} 2_{\mathrm{A}}$ receptor enhances smooth muscle contraction (162), and its polymorphism is suggested as a risk factor in IBS (163). Regarding the effect of androgens, a higher testosterone level is associated with higher serotonin tone in healthy men (164). Androgens upregulate 5-HT synthesis and SERT expression and ligand binding $(165,166)$. At the same time, serotonin modulates androgen reaction by suppressing AR activity (167).

Another important cellular component that is closely related to enteric nervous system differences in IBS are mast cells, which serve as neuroimmune effectors in the intestine. After activation, mast cells secrete mediators such as histamine and protease. These mediators signal to enteric neurons and induce visceral hypersensitivity or alter intestinal muscle contraction. In IBS, mast cell abundance is correlated with clinical symptoms including abdominal pain, bloating, and depression $(168,169)$ (170). Mast cell activity is also influenced by gender and sex steroids. In rodents, female mast cells release more histamine than male-derived cells in response to sex hormones (171). Also, female mice have higher mast cell capacity to synthesize and store mediators such as histamine, as well as experience greater intestinal permeability and serum histamine responses to restraint stress (172). In terms of hormonal effect, mast cells express estrogen receptors and are activated by estrogens. A previous study reported that estradiol binds to ER- $\alpha$ on mast cells and triggers activation via enhancing influx of extracellular Ca2+ (173). This effect is likely non-genomic due to the rapid onset of the response. Various studies have also demonstrated that estrogens can enhance mast cell numbers and their neuroimmune-targeted secretions (171-177). In contrast to estrogens, androgens appear to inhibit mast cell activity. A recent article reported that perinatal androgens reduce mast cell secretion and impart protection in mast-cell associated disease (178). Another study reported that exposure of human skin mast cells to testosterone reduced pro-inflammatory cytokine production, reflecting an anti-inflammatory response (179).

\section{GUT MICROBIOTA}

In recent years the notion of the gut-brain axis has been extended to include the microbiome, termed the 'microbiota-gut-brain axis' (180). The gastrointestinal tract harbors trillions of bacteria that signal via the gut-brain axis through many diverse interactions including serotonin release $(181,182)$. The gut microbiota play an important role in host health, and alterations in composition and function could contribute to IBS pathogenesis and therapeutic efficacy (183). Despite a lack of consensus on distinct microbial differences in IBS, intestinal microbiome features such as community richness has been proposed to correlate with severity of IBS symptoms (184, 185), but these findings are more often than not generalizable. Not only does the microbiota influence gut development and function, but it can also exert impact on extra-intestinal symptoms including depression (186). Importantly, it is highly likely that gut microbiota composition is influenced by IBS symptoms, particularly bowel movement which affect time and metabolic products that result from the interaction between the gut microbiota, host and dietary components.

Gut microbiota composition is closely associated with sex steroid levels in a reciprocal manner. In humans, systemic estradiol and testosterone are correlated with gut microbial diversity and profile in males and females $(187,188)$. The gut microbiota plays a pivotal role in regulating steroid metabolism, containing enzymes such as sulfatases and glucuronidases that deconjugate steroids for reabsorption in the intestine (189). Germ-free mice have high levels of fecal conjugated steroids (190), which is also observed after antibiotic use in humans, for example ampicillin use during pregnancy (191). Additionally, the gut microbiota degrade steroids into other metabolic products. Some bacteria influence the potency of estrogens by converting estrone into a more potent form estradiol and vice versa (192) (193). Specific bacteria e.g. Steroidobacter denitrificans and Comamonas testosteroni transform and utilize sex steroids $(194,195)$.

In addition to the modulation of steroid metabolism by microbes, sex steroids may also regulate gut microbiota community structure and function. Males and females exhibit 
different microbial profiles in animals and humans $(196,197)$. For example, Akkermansia is reported to be more abundant in females than in males $(198,199)$. Perturbations of sex hormones after ovariectomy or administration of sex steroids to animals shifts their gut microbiota profiles $(200,201)$. Steroids may also play a role in changing microbiome profiles during pregnancy and after menopause $(202,203)$, although several other factors undoubtedly influence these microbiota communities. Sex steroids influence gut microbiota by altering intestinal adaptive immune responses, as well as bacterial function. For instance, estrogens enhance the level of secretory immunoglobulin A (IgA) that binds to and controls bacterial growth (204). Conjugated estrogen and bazedoxifen reduce fecal $\beta$-glucuronidase (GUS) enzyme activity, which is involved in microbial deconjugation of steroids (205).

In view of the interplay between sex steroids and gut microbiota, bacteria could play an important role in mediating the effects of steroids and contribute to sexual dimorphism in IBS. This possibility is supported by the example of type 1 diabetes. As reported by a study in rodents, the femalepredominant incidence of type 1 diabetes is dependent on microbiota (206). Serum testosterone is higher in germ-free female mice than in SPF females, while the opposite is evident in males. Transfaunation of male cecal content into female weanlings not only alters the recipients' microbiome, but also increases their testosterone level and protects them from type 1 diabetes and autoimmune disease. Another study in mice demonstrated that the microbiota is closely associated with sex-bias in type 1 diabetes (196). Apart from type 1 diabetes, modulation of gut microbiota profiles by sex steroids also mediates their impact on metabolic syndrome (207). These studies provide insight for future studies to evaluate the association between sex steroids and the gut microbiota in IBS pathophysiology.

\section{EPIGENETIC MODULATION OF THE MICROBIOME-GUT-BRAIN-AXIS IN IBS}

IBS is a complex and multifactorial gut-brain axis disorder and epigenetics is believed to be one of the key mechanisms that links environmental factors to genetics in IBS. Epigenetics is the study of heritable changes of gene expression which are reversible and do not alter DNA sequence. The changes often involve mechanisms including DNA methylation, posttranslational histone modification and non-coding RNA. In an epigenetic model of IBS (208), it is proposed that early adverse life events result in epigenetic changes of the HPA-axis that subsequently alter responses to environmental stressor and enhanced cortisol production. Altered cytokine responses and 5-HT signaling pathways are affected and could contribute to the manifestation of IBS symptoms. In humans, genome-wide DNA methylation profiling of peripheral blood mononuclear cells of IBS patients identified various genes with altered DNA methylation status (209). In animal stress-induced IBS models, differentially methylated or expressed genes were identified, demonstrating the influence of stress on the epigenome (210). Furthermore, alteration of epigenetics by histone deacetylase inhibitor reduced visceral sensitivity in stressed animals (211). In our own studies, we have demonstrated that intestinal barrier dysfunction, is associated with epigenetic signals to early life stressors, and these mechanisms could be linked to intestinal inflammation and abdominal pain $(212,213)$.

Epigenetic changes are evident in response to various factors including dietary intake, physical activity and drugs. These factors are also closely associated with the gut microbiome, while the microbial metabolites influence epigenetics and drive host-microbial interaction. The gut microbiome mediates the effects of several environmental factors on enteric neurotransmission via epigenetic regulation (214). Low FODMAP diet, a low fermentable carbohydrates diet which improves IBS symptoms, modulates gut microbiota composition and reduces SCFAs which are recognized as histone deacetylase inhibitors and affect epigenetic processes. In a mouse study, gut microbiota regulated global histone acetylation and methylation, while the effect is disturbed by western diet consumption and is recapitulated by SCFAs supplementation (215). In another study, the SCFA butyrate contribute to the epigenetic effect on differentiation of colonic regulatory $\mathrm{T}$ cells (216). Other studies also demonstrated SCFA effects on histone modification in colon and brain in rodents $(217,218)$. These reports demonstrate that SCFAs are microbial products that can modulate epigenetic signals in IBS, possibly via altered microbiome-gut-brain axis signaling.

Sex steroids are also important epigenetic modulators. The crosstalk between the epigenome, sex steroids and their receptors is proposed as a mechanism for sexual dimorphism of nervous system and immune function. Estrogens and ER serve as epigenetic modulators through different mechanisms including alteration of DNA methylation (219) and histone modifications (220). These signals can influence various sex-dependent phenotypes, including enzyme expression, cognition and reproductive function (221). At the same time, epigenetic effects on ER result in changes in its gene expression and response to estrogen (222), as well as host phenotype including endocrine-resistance in breast cancer (223). Similar to estrogens, androgens and AR also possess epigenetic modulating effects. These signals are reported to be critical in polycystic ovary syndrome, in which hyperandrogenism is the primary feature $(224,225)$. Furthermore, epigenetic regulation of AR by DNA methylation and histone acetylation was suggested to be associated with endocrine disorder and prostate cancer (226, 227). Several studies have focused on association of early androgen exposure and the epigenome during neuronal developmental stages. Perinatal testosterone modulates histone acetylation during brain development in mice (228). Disruption of epigenetic modulation alters the masculinizing effect of testosterone on sexually dimorphic brain structure development in mice (229). Taken together, sex steroids and gut microbiota modulate host phenotype and the gut-brain axis through epigenetic mechanisms. Future studies investigating 
how epigenetics are involved in the interplay between microbiota and sex steroids in IBS are needed.

\section{CONCLUSION AND FUTURE PERSPECTIVES}

Sex steroids are closely associated with IBS onset and symptoms in multiple aspects. However, results regarding their exact role in IBS and underlying mechanisms have been inconsistent. At present, it is not clear whether an increase in sex steroids is beneficial or causative in IBS. This is partly explained by the complicated nature of steroid chemistry and their mechanism of action. Inconsistencies are also reflected in clinical cohort design and animal models used for study interpretation, emphasizing the need to stratify trial design by sex and standardizing treatment dose when studying sex steroids. Furthermore, whether gut microbiota can mediate the effects of sex steroids on IBS is still unclear and warrants further investigation as a precedent has already been set in other diseases. There is also little information about how adrenal androgens and the metabolic products of sex steroids are associated with IBS and gut-brain-axis signaling. This review provides a basis to continue

\section{REFERENCES}

1. Schmulson MJ, Drossman DA. What Is New in Rome Iv. J Neuro gastroenterol Motil (2017) 23:151-63. doi: 10.5056/jnm16214

2. Oka P, Parr H, Barberio B, Black C, Savarino E, Ford A. Global Prevalence of Irritable Bowel Syndrome According to Rome III or IV Criteria: A Systematic Review and Meta-Analysis. Lancet Gastroenterol Hepatol (2020) 5:908-17. doi: 10.1016/S2468-1253(20)30217-X

3. Fond G, Loundou A, Hamdani N, Boukouaci W, Dargel A, Oliveira J, et al. Anxiety and Depression Comorbidities in Irritable Bowel Syndrome (IBS): A Systematic Review and Meta-Analysis. Eur Arch Psychiatry Clin Neurosci (2014) 264:651-60. doi: 10.1007/s00406-014-0502-z

4. Han CJ, Yang GS. Fatigue in Irritable Bowel Syndrome: A Systematic Review and Meta-analysis of Pooled Frequency and Severity of Fatigue. Asian Nurs Res (Korean Soc Nurs Sci) (2016) 10:1-10. doi: 10.1016/j.anr.2016.01.003

5. Aziz I, Törnblom H, Palsson OS, Whitehead WE, Simrén M. How the Change in IBS Criteria From Rome III to Rome Iv Impacts on Clinical Characteristics and Key Pathophysiological Factors. Am J Gastroenterol (2018) 113:1017-25. doi: 10.1038/s41395-018-0074-Z

6. Narayanan SP, Anderson B, Bharucha AE. Sex- and Gender-Related Differences in Common Functional Gastroenterologic Disorders. Mayo Clin Proc (2021) 96:1071-89. doi: 10.1016/j.mayocp.2020.10.004

7. Camilleri M. Sex as a Biological Variable in Irritable Bowel Syndrome. Neurogastroenterol Motil Off J Eur Gastrointest Motil Soc (2020) 32:e13802. doi: $10.1111 / \mathrm{nmo} .13802$

8. Kim YS, Kim N. Sex-Gender Differences in Irritable Bowel Syndrome. J Neurogastroenterol Motil (2018) 24:544-58. doi: 10.5056/jnm18082

9. Bharadwaj S, Barber MD, Graff LA, Shen B. Symptomatology of Irritable Bowel Syndrome and Inflammatory Bowel Disease During the Menstrual Cycle. Gastroenterol Rep (2015) 3:185-93. doi: 10.1093/gastro/gov010

10. Saito YA. The Role of Genetics in IBS. Gastroenterol Clin North Am (2011) 40:45-67. doi: 10.1016/j.gtc.2010.12.011

11. Lovell R, Ford A. Effect of Gender on Prevalence of Irritable Bowel Syndrome in the Community: Systematic Review and Meta-Analysis. Am J Gastroenterol (2012) 107:991-1000. doi: 10.1038/ajg.2012.131

12. Rajindrajith S, Devanarayana NM. Subtypes and Symptomatology of Irritable Bowel Syndrome in Children and Adolescents: A School-Based the exploration of the complex interplay between sex steroids and metabolites, their receptors and the microbiome-gut-brain axis in the pathophysiology of IBS.

\section{AUTHOR CONTRIBUTIONS}

All authors contributed to the article and approved the submitted version. SS drafted the manuscript and created the figures, TS edited and finalized the manuscript.

\section{FUNDING}

This work was supported by NIH grants from NIDDK P30DK56338, NIAID R01-AI10091401, U01-AI24290 and P01AI152999, and NINR R01-NR013497.

\section{ACKNOWLEDGMENTS}

Figures were created using Biorender.com.

Survey Using Rome Iii Criteria. J Neurogastroenterol Motil (2012) 18:298304. doi: 10.5056/jnm.2012.18.3.298

13. Zhu X, Chen W, Zhu X, Shen Y. A Cross-Sectional Study of Risk Factors for Irritable Bowel Syndrome in Children 8-13 Years of Age in Suzhou, China. Gastroenterol Res Pract (2014) 2014:198461. doi: 10.1155/2014/198461

14. García Rodríguez LA, Wallander M-A, Johansson S, Olbe AR L. Detection of Colorectal Tumor and Inflammatory Bowel Disease During Follow-up of Patients With Initial Diagnosis of Irritable Bowel Syndrome. Scand J Gastroenterol (2000) 35:306-11. doi: 10.1080/003655200750024191

15. Triadafilopoulos G, Finlayson M, Grellet C. Bowel Dysfunction in Postmenopausal Women. Women Health (1998) 27:55-66. doi: 10.1300/ J013v27n04_04

16. Olafsdottir LB, Gudjonsson H, Jonsdottir HH, Björnsson E, Thjodleifsson B. Natural History of Irritable Bowel Syndrome in Women and Dysmenorrhea: A 10-Year Follow-Up Study. Gastroenterol Res Pract (2012) 2012:534204. doi: 10.1155/2012/534204

17. Herman J, Pokkunuri V, Braham L, Pimentel M. Gender Distribution in Irritable Bowel Syndrome is Proportional to the Severity of Constipation Relative to Diarrhea. Gend Med (2010) 7:240-6. doi: 10.1016/ j.genm.2010.06.007

18. Ghoshal UC, Abraham P, Bhatt C, Choudhuri G, Bhatia SJ, Shenoy KT, et al. Epidemiological and Clinical Profile of Irritable Bowel Syndrome in India: Report of the Indian Society of Gastroenterology Task Force. Indian J Gastroenterol Off J Indian Soc Gastroenterol (2008) 27:22-8.

19. Cui J, Shen Y, Li R. Estrogen Synthesis and Signaling Pathways During Aging: From Periphery to Brain. Trends Mol Med (2013) 19:197-209. doi: 10.1016/j.molmed.2012.12.007

20. Levin ER, Hammes SR. Nuclear Receptors Outside the Nucleus: Extranuclear Signalling by Steroid Receptors. Nat Rev Mol Cell Biol (2016) 17:783-97. doi: 10.1038/nrm.2016.122

21. Kalyvianaki K, Panagiotopoulos AA, Malamos P, Moustou E, Tzardi M, Stathopoulos EN, et al. Membrane Androgen Receptors (OXER1, GPRC6A and ZIP9) in Prostate and Breast Cancer: A Comparative Study of Their Expression. Steroids (2019) 142:100-8. doi: 10.1016/j.steroids.2019.01.006

22. Turcu A, Smith JM, Auchus R, Rainey WE. Adrenal Androgens and Androgen Precursors-Definition, Synthesis, Regulation and Physiologic Actions. Compr Physiol (2014) 4:1369-81. doi: 10.1002/cphy.c140006 
23. Storbeck K-H, Bloem LM, Africander D, Schloms L, Swart P, Swart AC. 11ßHydroxydihydrotestosterone and 11-Ketodihydrotestosterone, Novel C19 Steroids With Androgenic Activity: A Putative Role in Castration Resistant Prostate Cancer? Mol Cell Endocrinol (2013) 377:135-46. doi: 10.1016/ j.mce.2013.07.006

24. Rege J, Turcu AF, Kasa-Vubu JZ, Lerario AM, Auchus GC, Auchus RJ, et al. 11-Ketotestosterone Is the Dominant Circulating Bioactive Androgen During Normal and Premature Adrenarche. J Clin Endocrinol Metab (2018) 103:4589-98. doi: 10.1210/jc.2018-00736

25. Rege J, Nakamura Y, Satoh F, Morimoto R, Kennedy MR, Layman LC, et al. Liquid Chromatography-Tandem Mass Spectrometry Analysis of Human Adrenal Vein 19-Carbon Steroids Before and After Acth Stimulation. J Clin Endocrinol Metab (2013) 98:1182-8. doi: 10.1210/jc.2012-2912

26. Tajar A, Forti G, O'Neill TW, Lee DM, Silman AJ, Finn JD, et al. Characteristics of Secondary, Primary, and Compensated Hypogonadism in Aging Men: Evidence From the European Male Ageing Study. J Clin Endocrinol Metab (2010) 95:1810-8. doi: 10.1210/jc.2009-1796

27. Stanikova D, Zsido RG, Luck T, Pabst A, Enzenbach C, Bae YJ, et al. Testosterone Imbalance may Link Depression and Increased Body Weight in Premenopausal Women. Transl Psychiatry (2019) 9:160. doi: 10.1038/ s41398-019-0487-5

28. Majewska MD, Demirgo"ren S, Spivak CE, London ED. The Neurosteroid Dehydroepiandrosterone Sulfate is an Allosteric Antagonist of the GABAA Receptor. Brain Res (1990) 526:143-6. doi: 10.1016/0006-8993(90)90261-9

29. Weaver KR, Boulineaux CM, Robinson JM, Butler K, Heitkemper MM, Henderson WA. Sex Hormones, Bdnf, Leptin, and TGF- $\beta 1$ in Females With Ibs: A Pilot Investigation. Biol Res Nurs (2020) 23:231-7. doi: 10.1177/ 1099800420948589

30. Miller V, Whitaker K, Morris JA, Whorwell PJ. Gender and Irritable Bowel Syndrome: The Male Connection. J Clin Gastroenterol (2004) 38:558-60. doi: 10.1097/00004836-200408000-00004

31. Kim BJ, Rhee P-L, Park JH, Chang DK, Kim Y-H, Son HJ, et al. Male Sex Hormones May Influence the Symptoms of Irritable Bowel Syndrome in Young Men. Digestion (2008) 78:88-92. doi: 10.1159/000166600

32. Mathur R, Ko A, Hwang LJ, Low K, Azziz R, Pimentel M. Polycystic Ovary Syndrome Is Associated With an Increased Prevalence of Irritable Bowel Syndrome. Dig Dis Sci (2010) 55:1085-9. doi: 10.1007/s10620-009-0890-5

33. Adeyemo MA, Spiegel BMR, Chang L. Meta-Analysis: do Irritable Bowel Syndrome Symptoms Vary Between Men and Women? Aliment Pharmacol Ther (2010) 32:738-55. doi: 10.1111/j.1365-2036.2010.04409.x

34. Chang L, Mayer EA, Labus JS, Schmulson M, Lee OY, Olivas TI, et al. Effect of Sex on Perception of Rectosigmoid Stimuli in Irritable Bowel Syndrome. Am J Physiol Regul Integr Comp Physiol (2006) 291:R277-84. doi: 10.1152/ ajpregu.00729.2005

35. Naliboff BD, Berman S, Chang L, Derbyshire SWG, Suyenobu B, Vogt BA, et al. Sex-Related Differences in IBS Patients: Central Processing of Visceral Stimuli. Gastroenterology (2003) 124:1738-47. doi: 10.1016/s0016-5085(03) 00400-1

36. Icenhour A, Labrenz F, Roderigo T, Siebert C, Elsenbruch S, Benson S. Are There Sex Differences in Visceral Sensitivity in Young Healthy Men and Women? Neurogastroenterol Motil (2019) 31:e13664. doi: 10.1111/ nmo.13664

37. Hubbard CS, Karpowicz JM, Furman AJ, da Silva JT, Seminowicz DA, Traub RJ. Estrogen-Dependent Visceral Hypersensitivity Following Stress in Rats: An fMRI Study. Mol Pain (2016) 12:1744806916654145. doi: 10.1177/ 1744806916654145

38. Ji Y, Hu B, Li J, Traub RJ. Opposing Roles of Estradiol and Testosterone on Stress-Induced Visceral Hypersensitivity in Rats. J Pain (2018) 19:764-76. doi: 10.1016/j.jpain.2018.02.007

39. Lu C-L, Hsieh J-C, Tsaur M-L, Huang Y-H, Wang PS, Wu L-L, et al. Estrogen Rapidly Modulates Mustard Oil-Induced Visceral Hypersensitivity in Conscious Female Rats: A Role of CREB Phosphorylation in Spinal Dorsal Horn Neurons. Am J Physiol Liver Physiol (2007) 292:G438-46. doi: 10.1152/ ajpgi.00210.2006

40. Aloisi AM, Affaitati G, Ceccarelli I, Fiorenzani P, Lerza R, Rossi C, et al. Estradiol and Testosterone Differently Affect Visceral Pain-Related Behavioural Responses in Male and Female Rats. Eur J Pain (2010) 14:602-7. doi: 10.1016/j.ejpain.2009.10.016
41. Qin B, Dong L, Guo X, Jiang J, He Y, Wang X, et al. Expression of G ProteinCoupled Estrogen Receptor in Irritable Bowel Syndrome and its Clinical Significance. Int J Clin Exp Pathol (2014) 7:2238-46.

42. Amandusson A, Hallbeck M, Hallbeck AL, Hermanson O, Blomqvist A. Estrogen-Induced Alterations of Spinal Cord Enkephalin Gene Expression. Pain (1999) 83:243-8. doi: 10.1016/s0304-3959(99)00109-8

43. Taleghany N, Sarajari S, DonCarlos LL, Gollapudi L, Oblinger MM Differential Expression of Estrogen Receptor Alpha and Beta in Rat Dorsal Root Ganglion Neurons. J Neurosci Res (1999) 57:603-15. doi: 10.1002/(SICI)1097-4547(19990901)57:5<603::AID-JNR3>3.0.CO;2-R

44. Shughrue PJ, Lane MV, Merchenthaler I. Comparative Distribution of Estrogen Receptor-Alpha and -Beta mRNA in the Rat Central Nervous System. J Comp Neurol (1997) 388:507-25. doi: 10.1002/(sici)1096-9861 (19971201)388:4<507::aid-cne1>3.0.co;2-6

45. Sun L-H, Zhang W-X, Xu Q, Wu H, Jiao C-C, Chen X-Z. Estrogen Modulation of Visceral Pain. J Zhejiang Univ Sci B (2019) 20:628-36 doi: 10.1631/jzus.B1800582

46. Akbar A, Yiangou Y, Facer P, Walters JRF, Anand P, Ghosh S. Increased Capsaicin Receptor TRPV1-expressing Sensory Fibres in Irritable Bowel Syndrome and Their Correlation With Abdominal Pain. Gut (2008) 57:9239. doi: 10.1136/gut.2007.138982

47. Du Q, Liao Q, Chen C, Yang X, Xie R, Xu J. The Role of Transient Receptor Potential Vanilloid 1 in Common Diseases of the Digestive Tract and the Cardiovascular and Respiratory System. Front Physiol (2019) 10:1064 doi: 10.3389/fphys.2019.01064

48. Payrits M, Sághy É, Csekő K, Pohóczky K, Bölcskei K, Ernszt D, et al. Estradiol Sensitizes the Transient Receptor Potential Vanilloid 1 Receptor in Pain Responses. Endocrinology (2017) 158:3249-58. doi: 10.1210/en.201700101

49. Yamagata K, Sugimura M, Yoshida M, Sekine S, Kawano A, Oyamaguchi A et al. Estrogens Exacerbate Nociceptive Pain Via Up-Regulation of TRPV1 and ANO1 in Trigeminal Primary Neurons of Female Rats. Endocrinology (2016) 157:4309-17. doi: 10.1210/en.2016-1218

50. Greaves E, Grieve K, Horne AW, Saunders PTK. Elevated Peritoneal Expression and Estrogen Regulation of Nociceptive Ion Channels in Endometriosis. J Clin Endocrinol Metab (2014) 99:E1738-43. doi: 10.1210/ jc.2014-2282

51. Méndez-Reséndiz KA, Enciso-Pablo O, González-Ramírez R, JuárezContreras R, Rosenbaum T, Morales-Lázaro SL. Steroids and TRP Channels: A Close Relationship. Int J Mol Sci (2020) 21:3819. doi: 10.3390/ijms21113819

52. Smith YR, Stohler CS, Nichols TE, Bueller JA, Koeppe RA, Zubieta J-K Pronociceptive and Antinociceptive Effects of Estradiol Through Endogenous Opioid Neurotransmission in Women. J Neurosci (2006) 26:5777-85. doi: 10.1523/JNEUROSCI.5223-05.2006

53. Houghton LA, Jackson NA, Whorwell PJ, Morris J. Do Male Sex Hormones Protect From Irritable Bowel Syndrome? Am J Gastroenterol (2000) 95:2296-300. doi: 10.1016/S0002-9270(00)01106-0

54. Asuthkar S, Velpula KK, Elustondo PA, Demirkhanyan L, Zakharian E. TRPM8 Channel as a Novel Molecular Target in Androgen-Regulated Prostate Cancer Cells. Oncotarget (2015) 6:17221-36. doi: 10.18632/ oncotarget. 3948

55. Asuthkar S, Elustondo PA, Demirkhanyan L, Sun X, Baskaran P, Velpula KK, et al. The TRPM8 Protein is a Testosterone Receptor: I. Biochemical Evidence for Direct TRPM8-testosterone Interactions. J Biol Chem (2015) 290:2659-69. doi: 10.1074/jbc.M114.610824

56. Bidaux G, Roudbaraki M, Merle C, Crépin A, Delcourt P, Slomianny C, et al. Evidence for Specific TRPM8 Expression in Human Prostate Secretory Epithelial Cells: Functional Androgen Receptor Requirement. Endocr Relat Cancer (2005) 12:367-82. doi: 10.1677/erc.1.00969

57. Henström M, Hadizadeh F, Beyder A, Bonfiglio F, Zheng T, Assadi G, et al. TRPM8 Polymorphisms Associated With Increased Risk of IBS-C and IBSM. Gut (2017) 66:1725-7. doi: 10.1136/gutjnl-2016-313346

58. Harrington AM, Hughes PA, Martin CM, Yang J, Castro J, Isaacs NJ, et al. A Novel Role for TRPM8 in Visceral Afferent Function. PAIN ${ }^{\circledR}$ (2011) 152:1459-68. doi: 10.1016/j.pain.2011.01.027

59. Cappello G, Spezzaferro M, Grossi L, Manzoli L, Marzio L. Peppermint Oil (Mintoil $^{\circledR}$ ) in the Treatment of Irritable Bowel Syndrome: A Prospective 
Double Blind Placebo-Controlled Randomized Trial. Dig Liver Dis (2007) 39:530-6. doi: 10.1016/j.dld.2007.02.006

60. Ford AC, Talley NJ, Spiegel BMR, Foxx-Orenstein AE, Schiller L, Quigley EMM, et al. Effect of Fibre, Antispasmodics, and Peppermint Oil in the Treatment of Irritable Bowel Syndrome: Systematic Review and MetaAnalysis. BMJ (2008) 337:a2313. doi: 10.1136/bmj.a2313

61. Degen LP, Phillips SF. Variability of Gastrointestinal Transit in Healthy Women and Men. Gut (1996) 39:299-305. doi: 10.1136/gut.39.2.299

62. Fischer M, Fadda HM. The Effect of Sex and Age on Small Intestinal Transit Times in Humans. J Pharm Sci (2016) 105:682-6. doi: 10.1002/jps.24619

63. Sadik R, Abrahamsson H, Stotzer P-O. Gender Differences in Gut Transit Shown With a Newly Developed Radiological Procedure. Scand J Gastroenterol (2003) 38:36-42. doi: 10.1080/00365520310000410

64. Jung H-K, Kim D-Y, Moon I-H. Effects of Gender and Menstrual Cycle on Colonic Transit Time in Healthy Subjects. Korean J Intern Med (2003) 18:181-6. doi: 10.3904/kjim.2003.18.3.181

65. Al-Shboul AO, Nazzal SM, Mustafa GA, Al-Dwairi NA, Alqudah AM, Abu Omar A, et al. Estrogen Relaxes Gastric Muscle Cells Via a Nitric Oxideand Cyclic Guanosine Monophosphate-Dependent Mechanism: A Sex -Associated Differential Effect. Exp Ther Med (2018) 16:1685-92. doi: 10.3892/etm.2018.6406

66. Li Y, Xu J, Jiang F, Jiang Z, Liu C, Li L, et al. G Protein-Coupled Estrogen Receptor is Involved in Modulating Colonic Motor Function Via Nitric Oxide Release in C57BL/6 Female Mice. Neurogastroenterol Motil (2016) 28:432-42. doi: 10.1111/nmo.12743

67. Zielińska M, Fichna J, Bashashati M, Habibi S, Sibaev A, Timmermans J-P, et al. G Protein-Coupled Estrogen Receptor and Estrogen Receptor Ligands Regulate Colonic Motility and Visceral Pain. Neurogastroenterol Motil (2017) 29:e13025. doi: 10.1111/nmo.13025

68. Jacenik D, Cygankiewicz AI, Fichna J, Mokrowiecka A, Małecka-Panas E, Krajewska WM. Estrogen Signaling Deregulation Related With Local Immune Response Modulation in Irritable Bowel Syndrome. Mol Cell Endocrinol (2018) 471:89-96. doi: 10.1016/j.mce.2017.07.036

69. De Schepper HU, De Man JG, Ruyssers NE, Deiteren A, Van Nassauw L, Timmermans J-P, et al. TRPV1 Receptor Signaling Mediates Afferent Nerve Sensitization During Colitis-Induced Motility Disorders in Rats. Am J Physiol Liver Physiol (2008) 294:G245-53. doi: 10.1152/ajpgi.00351.2007

70. De Man JG, Boeckx S, Anguille S, De Winter BY, De Schepper HU, Herman AG, et al. Functional Study on TRPV1-mediated Signalling in the Mouse Small Intestine: Involvement of Tachykinin Receptors. Neurogastroenterol Motil (2008) 20:546-56. doi: 10.1111/j.1365-2982.2007.01064.x

71. Rahmati R. The Transient Receptor Potential Vanilloid Receptor 1, TRPV1 (VR1) Inhibits Peristalsis in the Mouse Jejunum. Arch Iran Med (2012) 15:433-8.

72. Szymaszkiewicz A, Włodarczyk J, Wasilewski A, Di Marzo V, Storr M, Fichna J, et al. Desensitization of Transient Receptor Potential Vanilloid Type-1 (TRPV1) Channel as Promising Therapy of Irritable Bowel Syndrome: Characterization of the Action of Palvanil in the Mouse Gastrointestinal Tract. Naunyn Schmiedebergs Arch Pharmacol (2020) 393:1357-64. doi: 10.1007/s00210-020-01829-x

73. Chen TS, Doong ML, Chang FY, Lee SD, Wang PS. Effects of Sex Steroid Hormones on Gastric Emptying and Gastrointestinal Transit in Rats. Am J Physiol Liver Physiol (1995) 268:G171-6. doi: 10.1152/ajpgi.1995.268.1.G171

74. González-Montelongo MC, Marín R, Gómez T, Marrero-Alonso J, Díaz M. Androgens Induce Nongenomic Stimulation of Colonic Contractile Activity Through Induction of Calcium Sensitization and Phosphorylation of LC20 and CPI-17. Mol Endocrinol (2010) 24:1007-23. doi: 10.1210/me.2009-0472

75. González-Montelongo M del C, Marin R, Gómez T, Diaz M. Androgens Differentially Potentiate Mouse Intestinal Smooth Muscle by Nongenomic Activation of Polyamine Synthesis and Rho Kinase Activation. Endocrinology (2007) 147:5715-29. doi: 10.1210/en.2006-0780

76. Blanchard EB, Keefer L, Galovski TE, Taylor AE, Turner SM. Gender Differences in Psychological Distress Among Patients With Irritable Bowel Syndrome. J Psychosom Res (2001) 50:271-5. doi: 10.1016/S0022-3999(01)00207-0

77. Tang Y, Yang W, Wang Y-L, Lin L. Sex Differences in the Symptoms and Psychological Factors That Influence Quality of Life in Patients With Irritable Bowel Syndrome. Eur J Gastroenterol Hepatol (2012) 24:702-7. doi: 10.1097/MEG.0b013e328351b2c2
78. Simrén M, Abrahamsson H, Svedlund J, Björnsson ES. Quality of Life in Patients With Irritable Bowel Syndrome Seen in Referral Centers Versus Primary Care: The Impact of Gender and Predominant Bowel Pattern. Scand J Gastroenterol (2001) 36:545-52. doi: 10.1080/003655201750153476

79. Kvrgic S, Harhaji S, Mijatovic Jovanovic V, Ac Nikolic E, Radic I, Cankovic S, et al. Gender Differences in Mental Health Among Adult Population in Vojvodina, Serbia. Iran J Public Health (2013) 42:833-41.

80. Matud MP, Bethencourt JM, Ibáñez I. Gender Differences in Psychological Distress in Spain. Int J Soc Psychiatry (2015) 61:560-8. doi: 10.1177/ 0020764014564801

81. Van Droogenbroeck F, Spruyt B, Keppens G. Gender Differences in Mental Health Problems Among Adolescents and the Role of Social Support: Results From the Belgian Health Interview Surveys 2008 and 2013. BMC Psychiatry (2018) 18:6. doi: 10.1186/s12888-018-1591-4

82. Hantsoo L, Epperson CN. Premenstrual Dysphoric Disorder: Epidemiology and Treatment. Curr Psychiatry Rep (2015) 17:87. doi: 10.1007/s11920-0150628-3

83. Borrow AP, Handa RJ. Estrogen Receptors Modulation of Anxiety-Like Behavior. Vitam Horm (2017) 103:27-52. doi: 10.1016/bs.vh.2016.08.004

84. Chen CV, Brummet JL, Lonstein JS, Jordan CL, Breedlove SM. New Knockout Model Confirms a Role for Androgen Receptors in Regulating Anxiety-Like Behaviors and HPA Response in Mice. Horm Behav (2014) 65:211-8. doi: 10.1016/j.yhbeh.2014.01.001

85. Walther A, Breidenstein J, Miller R. Association of Testosterone Treatment With Alleviation of Depressive Symptoms in Men: A Systematic Review and Meta-Analysis. JAMA Psychiatry (2019) 76:31-40. doi: 10.1001/ jamapsychiatry.2018.2734

86. Wong SYS, Leung JC, Kwok T, Ohlsson C, Vandenput L, Leung PC, et al. Low DHEAS Levels are Associated With Depressive Symptoms in Elderly Chinese Men: Results From a Large Study. Asian J Androl (2011) 13:898902. doi: 10.1038/aja.2011.116

87. Morsink LFJ, Vogelzangs N, Nicklas BJ, Beekman ATF, Satterfield S, Rubin SM, et al. Associations Between Sex Steroid Hormone Levels and Depressive Symptoms in Elderly Men and Women: Results From the Health ABC Study. Psychoneuroendocrinology (2007) 32:874-83. doi: 10.1016/j.psyneuen.2007.06.009

88. Wald A, Van Thiel DH, Hoechstetter L, Gavaler JS, Egler KM, Verm R, et al. Gastrointestinal Transit: The Effect of the Menstrual Cycle. Gastroenterol (New York NY 1943) (1981) 80:1497-500. doi: 10.1016/0016-5085(81)90263-8

89. Heitkemper MM, Chang L. Do Fluctuations in Ovarian Hormones Affect Gastrointestinal Symptoms in Women With Irritable Bowel Syndrome? Gend Med (2009) 6 Suppl 2:152-67. doi: 10.1016/j.genm.2009.03.004

90. Lee OY, Mayer EA, Schmulson M, Chang L, Naliboff B. Gender-Related Differences in IBS Symptoms. Am J Gastroenterol (2001) 96:2184-93. doi: 10.1016/S0002-9270(01)02524-2

91. Houghton LA, Lea R, Jackson N, Whorwell PJ. The Menstrual Cycle Affects Rectal Sensitivity in Patients With Irritable Bowel Syndrome But Not Healthy Volunteers. Gut (2002) 50:471-4. doi: 10.1136/gut.50.4.471

92. Hutson WR, Roehrkasse RL, Wald A. Influence of Gender and Menopause on Gastric Emptying and Motility. Gastroenterology (1989) 96:11-7. doi: 10.1016/0016-5085(89)90758-0

93. Chiloiro M, Darconza G, Piccioli E, De Carne M, Clemente C, Riezzo G. Gastric Emptying and Orocecal Transit Time in Pregnancy. J Gastroenterol (2001) 36:538-43. doi: 10.1007/s005350170056

94. Iwasaki H, Collins JG, Saito Y, Kerman-Hinds A. Naloxone-Sensitive, Pregnancy-Induced Changes in Behavioral Responses to Colorectal Distention: Pregnancy-Induced Analgesia to Visceral Stimulation Anesthesiol J Am Soc Anesthesiol Inc (1991) 74:927-33. doi: 10.1097/ 00000542-199105000-00019

95. van Kessel L, Teunissen D, Lagro-Janssen T. Sex-Gender Differences in the Effectiveness of Treatment of Irritable Bowel Syndrome: A Systematic Review. Int J Gen Med (2021) 14:867-84. doi: 10.2147/IJGM.S291964

96. Camilleri M, Mayer EA, Drossman DA, Heath A, Dukes GE, McSorley D, et al. Improvement in Pain and Bowel Function in Female Irritable Bowel Patients With Alosetron, a 5-HT3 Receptor Antagonist. Aliment Pharmacol Ther (1999) 13:1149-59. doi: 10.1046/j.1365-2036.1999.00610.x

97. Koch KM, Palmer JL, Noordin N, Tomlinson JJ, Baidoo C. Sex and Age Differences in the Pharmacokinetics of Alosetron. Br J Clin Pharmacol (2002) 53:238-42. doi: 10.1046/j.0306-5251.2001.01565.x 
98. Cash BD, Epstein MS, Shah SM. A Novel Delivery System of Peppermint Oil Is an Effective Therapy for Irritable Bowel Syndrome Symptoms. Dig Dis Sci (2016) 61:560-71. doi: 10.1007/s10620-015-3858-7

99. Labus JS, Dinov ID, Jiang Z, Ashe-McNalley C, Zamanyan A, Shi Y, et al. Irritable Bowel Syndrome in Female Patients is Associated With Alterations in Structural Brain Networks. Pain (2014) 155:137-49. doi: 10.1016/ j.pain.2013.09.020

100. Blankstein U, Chen J, Diamant NE, Davis KD. Altered Brain Structure in Irritable Bowel Syndrome: Potential Contributions of Pre-Existing and Disease-Driven Factors. Gastroenterology (2010) 138:1783-9. doi: 10.1053/ j.gastro.2009.12.043

101. Alzahrani MA, Alshamrani AS, Ahmasani IM, Alahmari FS, Asiri AH, Alshehri AM, et al. Coronavirus Disease 2019 Pandemic Stress and its Effects on Irritable Bowel Syndrome Patients in Saudi Arabia. Med (Baltimore) (2020) 99(51):e23711. doi: 10.1097/MD.0000000000023711

102. Drossman DA, Leserman J, Nachman G, Li ZM, Gluck H, Toomey TC, et al. Sexual and Physical Abuse in Women With Functional or Organic Gastrointestinal Disorders. Ann Intern Med (1990) 113:828-33. doi: 10.7326/0003-4819-113-11-828

103. Walker EA, Katon WJ, Roy-Byrne PP, Jemelka RP, Russo J. Histories of Sexual Victimization in Patients With Irritable Bowel Syndrome or Inflammatory Bowel Disease. Am J Psychiatry (1993) 150:1502-6. doi: 10.1176/ajp.150.10.1502

104. Bradford K, Shih W, Videlock EJ, Presson AP, Naliboff BD, Mayer EA, et al. Association Between Early Adverse Life Events and Irritable Bowel Syndrome. Clin Gastroenterol Hepatol (2012) 10:385-90.e903. doi: 10.1016/j.cgh.2011.12.018

105. Kanuri N, Cassell B, Bruce SE, White KS, Gott BM, Gyawali CP, et al. The Impact of Abuse and Mood on Bowel Symptoms and Health-Related Quality of Life in Irritable Bowel Syndrome (IBS). Neurogastroenterol Motil (2016) 28:1508-17. doi: 10.1111/nmo.12848

106. Heitkemper MM, Cain KC, Burr RL, Jun S-E, Jarrett ME. Is Childhood Abuse or Neglect Associated With Symptom Reports and Physiological Measures in Women With Irritable Bowel Syndrome? Biol Res Nurs (2011) 13:399-408. doi: 10.1177/1099800410393274

107. Smith SM, Vale WW. The Role of the Hypothalamic-Pituitary-Adrenal Axis in Neuroendocrine Responses to Stress. Dialogues Clin Neurosci (2006) 8:383-95. doi: 10.31887/DCNS.2006.8.4/ssmith

108. Chang L, Sundaresh S, Elliott J, Anton PA, Baldi P, Licudine A, et al. Dysregulation of the Hypothalamic-Pituitary-Adrenal (HPA) Axis in Irritable Bowel Syndrome. Neurogastroenterol Motil (2009) 21:149-59. doi: 10.1111/j.1365-2982.2008.01171.x

109. Fukudo S, Nomura T, Hongo M. Impact of Corticotropin-Releasing Hormone on Gastrointestinal Motility and Adrenocorticotropic Hormone in Normal Controls and Patients With Irritable Bowel Syndrome. Gut (1998) 42:845-9. doi: 10.1136/gut.42.6.845

110. Dinan TG, Quigley EMM, Ahmed SMM, Scully P, O’Brien S, O'Mahony L, et al. Hypothalamic-Pituitary-Gut Axis Dysregulation in Irritable Bowel Syndrome: Plasma Cytokines as a Potential Biomarker? Gastroenterology (2006) 130:304-11. doi: 10.1053/j.gastro.2005.11.033

111. Kano M, Muratsubaki T, Van Oudenhove L, Morishita J, Yoshizawa M, Kohno K, et al. Altered Brain and Gut Responses to Corticotropin-Releasing Hormone (CRH) in Patients With Irritable Bowel Syndrome. Sci Rep (2017) 7:12425. doi: 10.1038/s41598-017-09635-x

112. Böhmelt AH, Nater UM, Franke S, Hellhammer DH, Ehlert U. Basal and Stimulated Hypothalamic-Pituitary-Adrenal Axis Activity in Patients With Functional Gastrointestinal Disorders and Healthy Controls. Psychosom Med (2005) 67:288-94. doi: 10.1097/01.psy.0000157064.72831.ba

113. Videlock EJ, Shih W, Adeyemo M, Mahurkar-Joshi S, Presson AP, Polytarchou C, et al. The Effect of Sex and Irritable Bowel Syndrome on HPA Axis Response and Peripheral Glucocorticoid Receptor Expression. Psychoneuroendocrinology (2016) 69:67-76. doi: 10.1016/j.psyneuen.2016.03.016

114. Kirschbaum C, Kudielka BM, Gaab J, Schommer NC, Hellhammer DH. Impact of Gender, Menstrual Cycle Phase, and Oral Contraceptives on the Activity of the Hypothalamus-Pituitary-Adrenal Axis. Psychosom Med (1999) 61:154-62. doi: 10.1097/00006842-199903000-00006

115. Seale JV, Wood SA, Atkinson HC, Harbuz MS, Lightman SL. Gonadal Steroid Replacement Reverses Gonadectomy-Induced Changes in the
Corticosterone Pulse Profile and Stress-Induced Hypothalamic-PituitaryAdrenal Axis Activity of Male and Female Rats. J Neuroendocrinol (2004) 16:989-98. doi: 10.1111/j.1365-2826.2004.01258.x

116. Figueiredo HF, Ulrich-Lai YM, Choi DC, Herman JP. Estrogen Potentiates Adrenocortical Responses to Stress in Female Rats. Am J Physiol Metab (2007) 292:E1173-82. doi: 10.1152/ajpendo.00102.2006

117. Lund TD, Hinds LR, Handa RJ. The Androgen 5alpha-Dihydrotestosterone and its Metabolite 5alpha-androstan-3beta, 17beta-Diol Inhibit the Hypothalamo-Pituitary-Adrenal Response to Stress by Acting Through Estrogen Receptor Beta-Expressing Neurons in the Hypothalamus. J Neurosci (2006) 26:1448-56. doi: 10.1523/JNEUROSCI.3777-05.2006

118. Seale JV, Wood SA, Atkinson HC, Bate E, Lightman SL, Ingram CD, et al. Gonadectomy Reverses the Sexually Diergic Patterns of Circadian and Stress-Induced Hypothalamic-Pituitary-Adrenal Axis Activity In Male and Female Rats. J Neuroendocrinol (2004) 16:516-24. doi: 10.1111/j.13652826.2004.01195.x

119. Ochedalski T, Subburaju S, Wynn PC, Aguilera G. Interaction Between Oestrogen and Oxytocin on Hypothalamic-Pituitary-Adrenal Axis Activity. J Neuroendocrinol (2007) 19:189-97. doi: 10.1111/j.1365-2826.2006.01525.x

120. Young EA, Altemus M, Parkison V, Shastry S. Effects of Estrogen Antagonists and Agonists on the ACTH Response to Restraint Stress in Female Rats. Neuropsychopharmacology (2001) 25:881-91. doi: 10.1016/ S0893-133X(01)00301-3

121. Handa RJ, Weiser MJ. Gonadal Steroid Hormones and the HypothalamoPituitary-Adrenal Axis. Front Neuroendocrinol (2014) 35:197-220. doi: 10.1016/j.yfrne.2013.11.001

122. Kirschbaum C, Schommer N, Federenko I, Gaab J, Neumann O, Oellers M, et al. Short-Term Estradiol Treatment Enhances Pituitary-Adrenal Axis and Sympathetic Responses to Psychosocial Stress in Healthy Young Men. J Clin Endocrinol Metab (1996) 81:3639-43. doi: 10.1210/jcem.81.10.8855815

123. Kudielka BM, Schmidt-Reinwald AK, Hellhammer DH, Kirschbaum C. Psychological and Endocrine Responses to Psychosocial Stress and Dexamethasone/ Corticotropin-Releasing Hormone in Healthy Postmenopausal Women and Young Controls: The Impact of Age and a Two-Week Estradiol Treatment. Neuroendocrinology (1999) 70:422-30. doi: $10.1159 / 000054504$

124. Liu J, Bisschop PH, Eggels L, Foppen E, Fliers E, Zhou JN, et al. Intrahypothalamic Estradiol Modulates Hypothalamus-Pituitary-AdrenalAxis Activity in Female Rats. Endocrinology (2012) 153:3337-44. doi: 10.1210/en.2011-2176

125. Viau V, Meaney MJ. Testosterone-Dependent Variations in Plasma and Intrapituitary Corticosteroid Binding Globulin and Stress HypothalamicPituitary-Adrenal Activity in the Male Rat. J Endocrinol (2004) 181:223-31. doi: $10.1677 /$ joe. 0.1810223

126. Toufexis DJ, Wilson ME. Dihydrotestosterone Differentially Modulates the Cortisol Response of the Hypothalamic-Pituitary-Adrenal Axis in Male and Female Rhesus Macaques, and Restores Circadian Secretion of Cortisol in Females. Brain Res (2012) 1429:43-51. doi: 10.1016/j.brainres.2011.10.024

127. Rubinow DR, Roca CA, Schmidt PJ, Danaceau MA, Putnam K, Cizza G, et al. Testosterone Suppression of CRH-stimulated Cortisol in Men Neuropsychopharmacology (2005) 30:1906-12. doi: 10.1038/sj.npp.1300742

128. Zuloaga DG, Poort JE, Jordan CL, Breedlove SM. Male Rats With the Testicular Feminization Mutation of the Androgen Receptor Display Elevated Anxiety-Related Behavior and Corticosterone Response to Mild Stress. Horm Behav (2011) 60:380-8. doi: 10.1016/j.yhbeh.2011.07.008

129. Zuloaga DG, Morris JA, Jordan CL, Breedlove SM. Mice With the Testicular Feminization Mutation Demonstrate a Role for Androgen Receptors in the Regulation of Anxiety-Related Behaviors and the Hypothalamic-PituitaryAdrenal Axis. Horm Behav (2008) 54:758-66. doi: 10.1016/ j.yhbeh.2008.08.004

130. Tillisch K, Mayer EA, Labus JS, Stains J, Chang L, Naliboff BD. Sex Specific Alterations in Autonomic Function Among Patients With Irritable Bowel Syndrome. Gut (2005) 54:1396-401. doi: 10.1136/gut.2004.058685

131. Waring WS, Chui M, Japp A, Nicol EF, Ford MJ. Autonomic Cardiovascular Responses Are Impaired in Women With Irritable Bowel Syndrome. J Clin Gastroenterol (2004) 38:658-63. doi: 10.1097/01.mcg.0000135362.35665.49

132. Burr RL, Heitkemper M, Jarrett M, Cain KC. Comparison of Autonomic Nervous System Indices Based on Abdominal Pain Reports in Women With 
Irritable Bowel Syndrome. Biol Res Nurs (2000) 2:97-106. doi: 10.1177/ 109980040000200203

133. Heitkemper M, Jarrett M, Cain KC, Burr R, Levy RL, Feld A, et al. Autonomic Nervous System Function in Women With Irritable Bowel Syndrome. Dig Dis Sci (2001) 46:1276-84. doi: 10.1023/A:1010671514618

134. Yildirir A, Kabakci G, Akgul E, Tokgozoglu L, Oto A. Effects of Menstrual Cycle on Cardiac Autonomic Innervation as Assessed by Heart Rate Variability. Ann Noninvasive Electrocardiol (2002) 7:60-3. doi: 10.1111/ j.1542-474x.2001.tb00140.x

135. Mercuro G, Podda A, Pitzalis L, Zoncu S, Mascia M, Melis GB, et al. Evidence of a Role of Endogenous Estrogen in the Modulation of Autonomic Nervous System. Am J Cardiol (2000) 85:787-9. doi: 10.1016/S0002-9149(99)00865-6

136. Carnethon MR, Anthony MS, Cascio WE, Folsom AR, Rautaharju PM, Liao D, et al. Prospective Association Between Hormone Replacement Therapy, Heart Rate, and Heart Rate Variability: The Atherosclerosis Risk in Communities Study. J Clin Epidemiol (2003) 56:565-71. doi: 10.1016/ S0895-4356(03)00008-8

137. Virtanen I, Polo-Kantola P, Erkkola R, Polo O, Ekholm E. Climacteric Vasomotor Symptoms do Not Imply Autonomic Dysfunction. BJOG Int J Obstet Gynaecol (1999) 106:155-64. doi: 10.1111/j.1471-0528.1999.tb08216.x

138. Liu CC, Kuo TBJ, Yang CCH. Effects of Estrogen on Gender-Related Autonomic Differences in Humans. Am J Physiol Circ Physiol (2003) 285: H2188-93. doi: 10.1152/ajpheart.00256.2003

139. Rosano GMC, Patrizi R, Leonardo F, Ponikowski P, Collins P, Sarrel PM, et al. Effect of Estrogen Replacement Therapy on Heart Rate Variability and Heart Rate in HealthyPostmenopausal Women. Am J Cardiol (1997) 80:8157. doi: $10.1016 / \mathrm{S} 0002-9149(97) 00528-6$

140. Rosa Brito-Zurita O, Posadas-Romero C, Hermosillo AG, Zamora-González J, Hernández-Ono A, Cardoso-Saldaña G, et al. Estrogen Effect on Heart Rate Variability in Hypertensive Postmenopausal Women. Maturitas (2003) 44:39-48. doi: 10.1016/S0378-5122(02)00294-3

141. Liang Y, Yao S. Potential Role of Estrogen in Maintaining the Imbalanced Sympathetic and Sensory Innervation in Endometriosis. Mol Cell Endocrinol (2016) 424:42-9. doi: 10.1016/j.mce.2016.01.012

142. Doğru MT, Başar MM, Yuvanç E, Şimşek V, Şahin Ö. The Relationship Between Serum Sex Steroid Levels and Heart Rate Variability Parameters in Males and the Effect of Age. Arch Turkish Soc Cardiol (2010) 38:459-65.

143. Yildirir A, Aybar F, Kabakci G, Yarali H, Oto A. Heart Rate Variability in Young Women With Polycystic Ovary Syndrome. Ann Noninvasive Electrocardiol (2006) 11:306-12. doi: 10.1111/j.1542-474X.2006.00122.x

144. Nohara K, Waraich RS, Liu S, Ferron M, Waget A, Meyers MS, et al. Developmental Androgen Excess Programs Sympathetic Tone and Adipose Tissue Dysfunction and Predisposes to a Cardiometabolic Syndrome in Female Mice. Am J Physiol Endocrinol Metab (2013) 304:E1321-30. doi: 10.1152/ajpendo.00620.2012

145. Wranicz JK, Rosiak M, Cygankiewicz I, Kula P, Kula K, Zareba W. Sex Steroids and Heart Rate Variability in Patients After Myocardial Infarction. Ann Noninvasive Electrocardiol (2004) 9:156-61. doi: 10.1111/j.1542474X.2004.92539.x

146. Ramesh S, Wilton SB, Holroyd-Leduc JM, Turin TC, Sola DY, Ahmed SB. Testosterone is Associated With the Cardiovascular Autonomic Response to a Stressor in Healthy Men. Clin Exp Hypertens (2015) 37:184-91. doi: 10.3109/10641963.2014.933966

147. Niesler B, Kuerten S, Demir IE, Schäfer K-H. Disorders of the Enteric Nervous System - a Holistic View. Nat Rev Gastroenterol Hepatol (2021). doi: 10.1038/s41575-020-00385-2

148. Li S, Fei G, Fang X, Yang X, Sun X, Qian J, et al. Changes in Enteric Neurons of Small Intestine in a Rat Model of Irritable Bowel Syndrome With Diarrhea. J Neurogastroenterol Motil (2016) 22:310-20. doi: 10.5056/jnm15082

149. Medland JE, Pohl CS, Edwards LL, Frandsen S, Bagley K, Li Y, et al. Early Life Adversity in Piglets Induces Long-Term Upregulation of the Enteric Cholinergic Nervous System and Heightened, Sex-Specific Secretomotor Neuron Responses. Neurogastroenterol Motil (2016) 28:1317-29. doi: $10.1111 /$ nmo. 12828

150. Makowska K, Gonkowski S. Age and Sex-Dependent Differences in the Neurochemical Characterization of Calcitonin Gene-Related Peptide-Like Immunoreactive (Cgrp-Li) Nervous Structures in the Porcine Descending Colon. Int J Mol Sci (2019) 20:1024. doi: 10.3390/ijms20051024
151. Crowell MD. Role of Serotonin in the Pathophysiology of the Irritable Bowel Syndrome. Br J Pharmacol (2004) 141:1285-93. doi: 10.1038/sj.bjp.0705762

152. Mawe GM, Hoffman JM. Serotonin Signalling in the Gut-Functions, Dysfunctions and Therapeutic Targets. Nat Rev Gastroenterol Hepatol (2013) 10:473-86. doi: 10.1038/nrgastro.2013.105

153. Nishizawa S, Benkelfat C, Young SN, Leyton M, Mzengeza S, de Montigny C, et al. Differences Between Males and Females in Rates of Serotonin Synthesis in Human Brain. Proc Natl Acad Sci U S A (1997) 94:5308-13. doi: 10.1073/ pnas. 94.10 .5308

154. Nakai A, Kumakura Y, Boivin M, Rosa P, Diksic M, D’Souza D, et al. Sex Differences of Brain Serotonin Synthesis in Patient With Irritable Bowel Syndrome Using $\alpha$-[11c]methyl-L-tryptophan, Positron Emission Tomogrpahy and Statistical Parametric Mapping. Can J Gastroenterol (2003) 17:191-6. doi: 10.1155/2003/572127

155. Pecins-Thompson M, Brown NA, Kohama SG, Bethea CL. Ovarian Steroid Regulation of Tryptophan Hydroxylase Mrna Expression in Rhesus Macaques. J Neurosci (1996) 16:7021-9. doi: 10.1523/JNEUROSCI.16-2107021.1996

156. Bethea CL, Smith AW, Centeno ML, Reddy AP. Long-Term Ovariectomy Decreases Serotonin Neuron Number and Gene Expression in Free Ranging Macaques. Neuroscience (2011) 192:675-88. doi: 10.1016/j.neuroscience. 2011.06.003

157. Shors TJ, Leuner B. Estrogen-Mediated Effects on Depression and Memory Formation in Females. J Affect Disord (2003) 74:85-96. doi: 10.1016/s01650327(02)00428-7

158. Pecins-Thompson M A, Brown N, Bethea CL. Regulation of Serotonin ReUptake Transporter mRNA Expression by Ovarian Steroids in Rhesus Macaques. Mol Brain Res (1998) 53:120-9. doi: 10.1016/S0169-328X(97) 00286-6

159. Smith LJ, Henderson JA, Abell CW, Bethea CL. Effects of Ovarian Steroids and Raloxifene on Proteins That Synthesize, Transport, and Degrade Serotonin in the Raphe Region of Macaques. Neuropsychopharmacology (2004) 29:2035-45. doi: 10.1038/sj.npp.1300510

160. Kugaya A, Epperson CN, Zoghbi S, van Dyck CH, Hou Y, Fujita M, et al. Increase in Prefrontal Cortex Serotonin2A Receptors Following Estrogen Treatment in Postmenopausal Women. Am J Psychiatry (2003) 160:1522-4. doi: 10.1176/appi.ajp.160.8.1522

161. Moses-Kolko EL, Berga SL, Greer PJ, Smith G, Cidis Meltzer C, Drevets WC. Widespread Increases of Cortical Serotonin Type 2A Receptor Availability After Hormone Therapy in Euthymic Postmenopausal Women. Fertil Steril (2003) 80:554-9. doi: 10.1016/S0015-0282(03)00973-7

162. Fiorica-Howells E, Hen R, Gingrich J, Li Z, Gershon MD. 5-HT2A Receptors: Location and Functional Analysis in Intestines of Wild-Type and 5-HT2A Knockout Mice. Am J Physiol Liver Physiol (2002) 282:G877-93. doi: 10.1152/ajpgi.00435.2001

163. Markoutsaki T, Karantanos T, Gazouli M, Anagnou NP, Karamanolis DG. 5Ht2a Receptor Gene Polymorphisms and Irritable Bowel Syndrome. J Clin Gastroenterol (2011) 45:514-7. doi: 10.1097/MCG.0b013e318205e13b

164. Perfalk E, da Cunha-Bang S, Holst KK, Keller S, Svarer C, Knudsen GM, et al. Testosterone Levels in Healthy Men Correlate Negatively With Serotonin 4 Receptor Binding. Psychoneuroendocrinology (2017) 81:22-8. doi: 10.1016/ j.psyneuen.2017.03.018

165. Kranz GS, Wadsak W, Kaufmann U, Savli M, Baldinger P, Gryglewski G, et al. High-Dose Testosterone Treatment Increases Serotonin Transporter Binding in Transgender People. Biol Psychiatry (2015) 78:525-33. doi: 10.1016/j.biopsych.2014.09.010

166. Bethea CL, Coleman K, Phu K, Reddy AP, Phu A. Relationships Between Androgens, Serotonin Gene Expression and Innervation in Male Macaques. Neuroscience (2014) 274:341-56. doi: 10.1016/j.neuroscience.2014.05.056

167. Carvalho-Dias E, Miranda A, Martinho O, Mota P, Costa Â, Nogueira-Silva C, et al. Serotonin Regulates Prostate Growth Through Androgen Receptor Modulation. Sci Rep (2017) 7:15428. doi: 10.1038/s41598-017-15832-5

168. Barbara G, Stanghellini V, De Giorgio R, Cremon C, Cottrell GS, Santini D, et al. Activated Mast Cells in Proximity to Colonic Nerves Correlate With Abdominal Pain in Irritable Bowel Syndrome. Gastroenterology (2004) 126:693-702. doi: 10.1053/j.gastro.2003.11.055

169. Cremon C, Gargano L, Morselli-Labate AM, Santini D, Cogliandro RF, De Giorgio R, et al. Mucosal Immune Activation in Irritable Bowel Syndrome: 
Gender-Dependence and Association With Digestive Symptoms. Am J Gastroenterol (2009) 104:392-400. doi: 10.1038/ajg.2008.94

170. Piche T, Saint-Paul MC, Dainese R, Marine-Barjoan E, Iannelli A, Montoya ML, et al. Mast Cells and Cellularity of the Colonic Mucosa Correlated With Fatigue and Depression in Irritable Bowel Syndrome. Gut (2008) 57:468-73. doi: 10.1136/gut.2007.127068

171. Muñoz-Cruz S, Mendoza-Rodríguez Y, Nava-Castro KE, Yepez-Mulia L, Morales-Montor J. Gender-Related Effects of Sex Steroids on Histamine Release and Fceri Expression in Rat Peritoneal Mast Cells. J Immunol Res (2015) 2015:351829. doi: 10.1155/2015/351829

172. Mackey E, Ayyadurai S, Pohl CS, D'Costa S, Li Y, Moeser AJ. Sexual Dimorphism in the Mast Cell Transcriptome and the Pathophysiological Responses to Immunological and Psychological Stress. Biol Sex Differ (2016) 7:60. doi: 10.1186/s13293-016-0113-7

173. Zaitsu M, Narita S-I, Lambert KC, Grady JJ, Estes DM, Curran EM, et al. Estradiol Activates Mast Cells Via a non-Genomic Estrogen Receptor-Alpha and Calcium Influx. Mol Immunol (2007) 44:1977-85. doi: 10.1016/ j.molimm.2006.09.030

174. Jing H, Wang Z, Chen Y. Effect of Oestradiol on Mast Cell Number and Histamine Level in the Mammary Glands of Rat. Anat Histol Embryol (2012) 41:170-6. doi: 10.1111/j.1439-0264.2011.01120.x

175. Narita S, Goldblum RM, Watson CS, Brooks EG, Estes DM, Curran EM, et al. Environmental Estrogens Induce Mast Cell Degranulation and Enhance IgE-mediated Release of Allergic Mediators. Environ Health Perspect (2007) 115:48-52. doi: 10.1289/ehp.9378

176. Vliagoftis H, Dimitriadou V, Boucher W, Rozniecki JJ, Correia I, Raam S, et al. Estradiol Augments While Tamoxifen Inhibits Rat Mast Cell Secretion. Int Arch Allergy Immunol (1992) 98:398-409. doi: 10.1159/000236217

177. Di Matteo L, Chieffi Baccari G, Chieffi P, Minucci S. The Effects of Testosterone and Estradiol on Mast Cell Number in the Harderian Gland of the Frog, Rana Esculenta. Zoolog Sci (1995) 12:457-66. doi: 10.2108/ zsj. 12.457

178. Mackey E, Thelen KM, Bali V, Fardisi M, Trowbridge M, Jordan CL, et al. Perinatal Androgens Organize Sex Differences in Mast Cells and Attenuate Anaphylaxis Severity Into Adulthood. Proc Natl Acad Sci (2020) 117:2375161. doi: 10.1073/pnas.1915075117

179. Guhl S, Artuc M, Zuberbier T, Babina M. Testosterone Exerts Selective AntiInflammatory Effects on Human Skin Mast Cells in a Cell Subset Dependent Manner. Exp Dermatol (2012) 21:878-80. doi: 10.1111/exd.12006

180. Mayer EA, Savidge T, Shulman RJ. Brain-Gut Microbiome Interactions and Functional Bowel Disorders. Gastroenterology (2014) 146:1500-12. doi: 10.1053/j.gastro.2014.02.037

181. Cryan JF, O'Riordan KJ, Cowan CSM, Sandhu KV, Bastiaanssen TFS, Boehme M, et al. The Microbiota-Gut-Brain Axis. Physiol Rev (2019) 99:1877-2013. doi: 10.1152/physrev.00018.2018

182. Foong JPP, Hung LY, Poon S, Savidge TC, Bornstein JC. Early Life Interaction Between the Microbiota and the Enteric Nervous System. Am J Physiol Gastrointest liver Physiol (2020) 319:G541-8. doi: 10.1152/ ajpgi.00288.2020

183. Chumpitazi BP, Hollister EB, Oezguen N, Tsai CM, McMeans AR, Luna RA, et al. Gut Microbiota Influences Low Fermentable Substrate Diet Efficacy in Children With Irritable Bowel Syndrome. Gut Microbes (2014) 5:165-75. doi: 10.4161 /gmic.27923

184. Tap J, Derrien M, Törnblom H, Brazeilles R, Cools-Portier S, Doré J, et al. Identification of an Intestinal Microbiota Signature Associated With Severity of Irritable Bowel Syndrome. Gastroenterology (2017) 152:111-23.e8. doi: 10.1053/j.gastro.2016.09.049

185. Labus JS, Hollister EB, Jacobs J, Kirbach K, Oezguen N, Gupta A, et al. Differences in Gut Microbial Composition Correlate With Regional Brain Volumes in Irritable Bowel Syndrome. Microbiome (2017) 5:49. doi: 10.1186/ s40168-017-0260-z

186. Valles-Colomer M, Falony G, Darzi Y, Tigchelaar EF, Wang J, Tito RY, et al. The Neuroactive Potential of the Human Gut Microbiota in Quality of Life and Depression. Nat Microbiol (2019) 4:623-32. doi: 10.1038/s41564-018-0337-x

187. Shin J-H, Park Y-H, Sim M, Kim S-A, Joung H, Shin D-M. Serum Level of Sex Steroid Hormone is Associated With Diversity and Profiles of Human Gut Microbiome. Res Microbiol (2019) 170:192-201. doi: 10.1016/ j.resmic.2019.03.003
188. Flores R, Shi J, Fuhrman B, Xu X, Veenstra TD, Gail MH, et al. Fecal Microbial Determinants of Fecal and Systemic Estrogens and Estrogen Metabolites: A Cross-Sectional Study. J Transl Med (2012) 10:253. doi: 10.1186/1479-5876-10-253

189. Pace F, Watnick PI. The Interplay of Sex Steroids, the Immune Response, and the Intestinal Microbiota. Trends Microbiol (2020). doi: 10.1016/ j.tim.2020.11.001

190. Colldén H, Landin A, Wallenius V, Elebring E, Fändriks L, Nilsson ME, et al. The Gut Microbiota is a Major Regulator of Androgen Metabolism in Intestinal Contents. Am J Physiol Metab (2019) 317:E1182-92. doi: 10.1152/ajpendo.00338.2019

191. Martin F, Peltonen J, Laatikainen T, Pulkkinen M, Adlercreutz H. Excretion of Progesteone Metabolites and Estriol in Faeces From Pregnant Women During Ampicillin Administration. J Steroid Biochem (1975) 6:1339-46. doi: 10.1016/0022-4731(75)90363-5

192. Järvenpää $\mathrm{P}$, Kosunen T, Fotsis T, Adlercreutz H. In Vitro Metabolism of Estrogens by Isolated Intestinal Micro-Organisms and by Human Faecal Microflora. J Steroid Biochem (1980) 13:345-9. doi: 10.1016/0022-4731(80) 90014-X

193. Tamura M, Hori S, Nakagawa H. Intestinal Bacterium Tm-30: An S-equolproducing Bacterium Isolated From Human Feces is Involved in Estrogen Metabolism In Vitro. Food Sci Technol Res (2014) 20:309-16. doi: 10.3136/ fstr.20.309

194. Wang P-H, Leu Y-L, Ismail W, Tang S-L, Tsai C-Y, Chen H-J, et al. Anaerobic and Aerobic Cleavage of the Steroid Core Ring Structure by Steroidobacter Denitrificans[s]. J Lipid Res (2013) 54:1493-504. doi: 10.1194/ jlr.M034223

195. Zhang H, Ji Y, Wang Y, Zhang X, Yu Y. Cloning and Characterization of a Novel $\beta$-ketoacyl-ACP Reductase From Comamonas Testosteroni. Chem Biol Interact (2015) 234:213-20. doi: 10.1016/j.cbi.2015.01.003

196. Yurkovetskiy L, Burrows M, Khan AA, Graham L, Volchkov P, Becker L et al. Gender Bias in Autoimmunity is Influenced by Microbiota. Immunity (2013) 39:400-12. doi: 10.1016/j.immuni.2013.08.013

197. Mueller S, Saunier K, Hanisch C, Norin E, Alm L, Midtvedt T, et al. Differences in Fecal Microbiota in Different European Study Populations in Relation to Age, Gender, and Country: A Cross-Sectional Study. Appl Environ Microbiol (2006) 72:1027-33. doi: 10.1128/AEM.72.2.10271033.2006

198. Sinha T, Vich Vila A, Garmaeva S, Jankipersadsing SA, Imhann F, Collij V, et al. Analysis of 1135 Gut Metagenomes Identifies Sex-Specific Resistome Profiles. Gut Microbes (2019) 10:358-66. doi: 10.1080/19490976.2018.1528822

199. Takagi T, Naito Y, Inoue R, Kashiwagi S, Uchiyama K, Mizushima K, et al. Differences in Gut Microbiota Associated With Age, Sex, and Stool Consistency in Healthy Japanese Subjects. J Gastroenterol (2019) 54:53-63. doi: 10.1007/s00535-018-1488-5

200. Moreno-Indias I, Sánchez-Alcoholado L, Sánchez-Garrido MÁ, MartínNúñez GM, Pérez-Jiménez F, Tena-Sempere M, et al. Neonatal Androgen Exposure Causes Persistent Gut Microbiota Dysbiosis Related to Metabolic Disease in Adult Female Rats. Endocrinology (2016) 157:4888-98. doi: 10.1210/en.2016-1317

201. Song C-H, Kim N, Nam RH, Choi SI, Lee H-N, Surh Y-J. 17ß-Estradiol Supplementation Changes Gut Microbiota Diversity in Intact and Colorectal Cancer-Induced ICR Male Mice. Sci Rep (2020) 10:12283. doi: 10.1038/ s41598-020-69112-w

202. Koren O, Goodrich JK, Cullender TC, Spor A, Laitinen K, Bäckhed HK, et al. Host Remodeling of the Gut Microbiome and Metabolic Changes During Pregnancy. Cell (2012) 150:470-80. doi: 10.1016/j.cell.2012.07.008

203. Zhao H, Chen J, Li X, Sun Q, Qin P, Wang Q. Compositional and Functional Features of the Female Premenopausal and Postmenopausal Gut Microbiota. FEBS Lett (2019) 593:2655-64. doi: 10.1002/1873-3468.13527

204. Diebel ME, Diebel LN, Liberati DM. Gender Dimorphism in the Gut: Mucosal Protection by Estrogen Stimulation of IgA Transcytosis. J Trauma (2011) 71:474-9. doi: 10.1097/ta.0b013e318228239d

205. Chen KLA, Liu X, Zhao YC, Hieronymi K, Rossi G, Auvil LS, et al. LongTerm Administration of Conjugated Estrogen and Bazedoxifene Decreased Murine Fecal $\beta$-Glucuronidase Activity Without Impacting Overall Microbiome Community. Sci Rep (2018) 8:8166. doi: 10.1038/s41598-01826506-1 
206. Markle JGM, Frank DN, Mortin-Toth S, Robertson CE, Feazel LM, RolleKampczyk U, et al. Sex Differences in the Gut Microbiome Drive HormoneDependent Regulation of Autoimmunity. Sci (80- ) (2013) 339:1084-8. doi: 10.1126/science.1233521

207. Kaliannan K, Robertson RC, Murphy K, Stanton C, Kang C, Wang B, et al. Estrogen-Mediated Gut Microbiome Alterations Influence Sexual Dimorphism in Metabolic Syndrome in Mice. Microbiome (2018) 6:205. doi: 10.1186/s40168-018-0587-0

208. Dinan TG, Cryan J, Shanahan F, Keeling PWN, Quigley EMM. IBS: An Epigenetic Perspective. Nat Rev Gastroenterol Hepatol (2010) 7:465-71. doi: 10.1038/nrgastro.2010.99

209. Mahurkar S, Polytarchou C, Iliopoulos D, Pothoulakis C, Mayer EA, Chang L. Genome-Wide DNA Methylation Profiling of Peripheral Blood Mononuclear Cells in Irritable Bowel Syndrome. Neurogastroenterol Motil (2016) 28:410-22. doi: 10.1111/nmo.12741

210. Zhu S, Min L, Guo Q, Li H, Yu Y, Zong Y, et al. Transcriptome and Methylome Profiling in a Rat Model of Irritable Bowel Syndrome Induced by Stress. Int J Mol Med (2018) 42:2641-9. doi: 10.3892/ijmm.2018.3823

211. Tran L, Chaloner A, Sawalha AH, Greenwood Van-Meerveld B. Importance of Epigenetic Mechanisms in Visceral Pain Induced by Chronic Water Avoidance Stress. Psychoneuroendocrinology (2013) 38:898-906. doi: 10.1016/j.psyneuen.2012.09.016

212. Kline KT, Lian H, Zhong XS, Luo X, Winston JH, Cong Y, et al. Neonatal Injury Increases Gut Permeability by Epigenetically Suppressing E-Cadherin in Adulthood. J Immunol (2020) 204:980-9. doi: 10.4049/jimmunol.1900639

213. Zhong XS, Winston JH, Luo X, Kline KT, Nayeem SZ, Cong Y, et al. Neonatal Colonic Inflammation Epigenetically Aggravates Epithelial Inflammatory Responses to Injury in Adult Life. Cell Mol Gastroenterol Hepatol (2018) 6:65-78. doi: 10.1016/j.jcmgh.2018.02.014

214. Savidge TC. Epigenetic Regulation of Enteric Neurotransmission by Gut Bacteria. Front Cell Neurosci (2016) 9:503. doi: 10.3389/fncel.2015.00503

215. Krautkramer KA, Kreznar JH, Romano KA, Vivas EI, Barrett-Wilt GA, Rabaglia ME, et al. Diet-Microbiota Interactions Mediate Global Epigenetic Programming in Multiple Host Tissues. Mol Cell (2016) 64:982-92. doi: 10.1016/j.molcel.2016.10.025

216. Furusawa Y, Obata Y, Fukuda S, Endo TA, Nakato G, Takahashi D, et al. Commensal Microbe-Derived Butyrate Induces the Differentiation of Colonic Regulatory T Cells. Nature (2013) 504:446-50. doi: 10.1038/nature12721

217. Fellows R, Denizot J, Stellato C, Cuomo A, Jain P, Stoyanova E, et al. Microbiota Derived Short Chain Fatty Acids Promote Histone Crotonylation in the Colon Through Histone Deacetylases. Nat Commun (2018) 9:105. doi: 10.1038/s41467-017-02651-5

218. Soliman ML, Rosenberger TA. Acetate Supplementation Increases Brain Histone Acetylation and Inhibits Histone Deacetylase Activity and Expression. Mol Cell Biochem (2011) 352:173-80. doi: 10.1007/s11010-011-0751-3

219. Yang Y-M, Sun D, Kandhi S, Froogh G, Zhuge J, Huang W, et al. EstrogenDependent Epigenetic Regulation of Soluble Epoxide Hydrolase Via DNA Methylation. Proc Natl Acad Sci U S A (2018) 115:613-8. doi: 10.1073/ pnas. 1716016115
220. Dumasia K, Kumar A, Deshpande S, Balasinor NH. Estrogen, Through Estrogen Receptor 1, Regulates Histone Modifications and Chromatin Remodeling During Spermatogenesis in Adult Rats. Epigenetics (2017) 12:953-63. doi: 10.1080/15592294.2017.1382786

221. Fortress AM, Kim J, Poole RL, Gould TJ, Frick KM. 17ß-Estradiol Regulates Histone Alterations Associated With Memory Consolidation and Increases Bdnf Promoter Acetylation in Middle-Aged Female Mice. Learn Mem (2014) 21:457-67. doi: 10.1101/lm.034033.113

222. Zhang X, Tanaka K, Yan J, Li J, Peng D, Jiang Y, et al. Regulation of Estrogen Receptor $\alpha$ by Histone Methyltransferase SMYD2-mediated Protein Methylation. Proc Natl Acad Sci (2013) 110:17284-9. doi: 10.1073/ pnas. 1307959110

223. Achinger-Kawecka J, Valdes-Mora F, Luu P-L, Giles KA, Caldon CE, Qu W, et al. Epigenetic Reprogramming At Estrogen-Receptor Binding Sites Alters 3D Chromatin Landscape in Endocrine-Resistant Breast Cancer. Nat Commun (2020) 11:320. doi: 10.1038/s41467-019-14098-x

224. Kokosar M, Benrick A, Perfilyev A, Fornes R, Nilsson E, Maliqueo M, et al. Epigenetic and Transcriptional Alterations in Human Adipose Tissue of Polycystic Ovary Syndrome. Sci Rep (2016) 6:22883. doi: 10.1038/ srep22883

225. Sinha N, Roy S, Huang B, Wang J, Padmanabhan V, Sen A. Developmental Programming: Prenatal Testosterone-Induced Epigenetic Modulation and its Effect on Gene Expression in Sheep Ovary†. Biol Reprod (2020) 102:1045-54. doi: 10.1093/biolre/ioaa007

226. Nakayama T, Watanabe M, Suzuki H, Toyota M, Sekita N, Hirokawa Y, et al. Epigenetic Regulation of Androgen Receptor Gene Expression in Human Prostate Cancers. Lab Investig (2000) 80:1789-96. doi: 10.1038/ labinvest. 3780190

227. Hornig NC, Rodens P, Dörr H, Hubner NC, Kulle AE, Schweikert H-U, et al. Epigenetic Repression of Androgen Receptor Transcription in MutationNegative Androgen Insensitivity Syndrome (Ais Type Ii). J Clin Endocrinol Metab (2018) 103:4617-27. doi: 10.1210/jc.2018-00052

228. Tsai H-W, Grant PA, Rissman EF. Sex Differences in Histone Modifications in the Neonatal Mouse Brain. Epigenetics (2009) 4:47-53. doi: 10.4161/ epi.4.1.7288

229. Murray EK, Hien A, de Vries GJ, Forger NG. Epigenetic Control of Sexual Differentiation of the Bed Nucleus of the Stria Terminalis. Endocrinology (2009) 150:4241-7. doi: 10.1210/en.2009-0458

Conflict of Interest: The authors declare that the research was conducted in the absence of any commercial or financial relationships that could be construed as a potential conflict of interest.

Copyright (c) 2021 So and Savidge. This is an open-access article distributed under the terms of the Creative Commons Attribution License (CC BY). The use, distribution or reproduction in other forums is permitted, provided the original author(s) and the copyright owner(s) are credited and that the original publication in this journal is cited, in accordance with accepted academic practice. No use, distribution or reproduction is permitted which does not comply with these terms. 